\title{
Handbook on the Material Properties of Yttrium Hydride for High- Temperature Moderator Applications
}

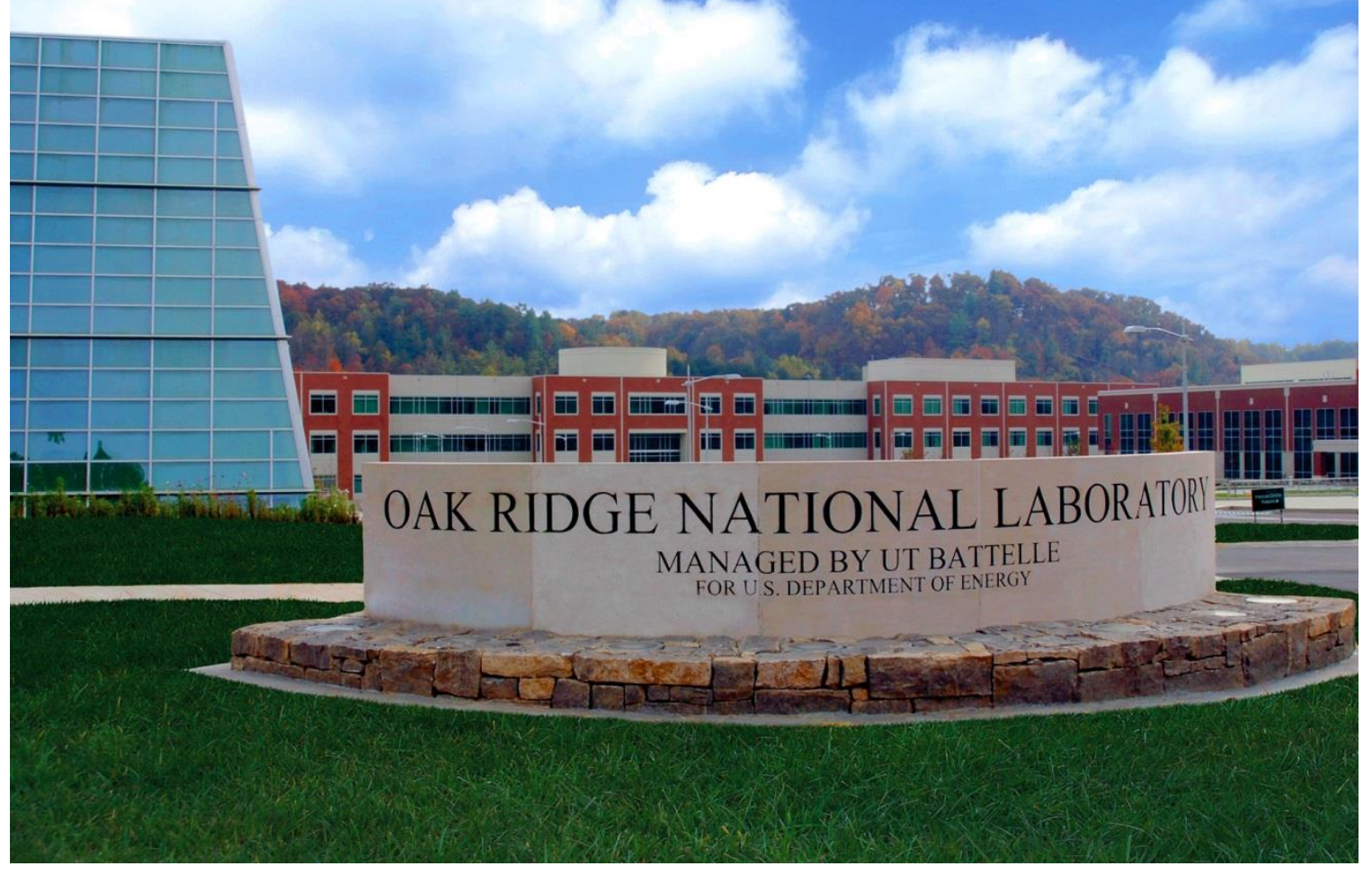

Xunxiang $\mathrm{Hu}$

Hsin Wang

Kory Linton

Annabelle Le Coq

Kurt A. Terrani

Approved for public release.

June 2021

Distribution is unlimited.

M2TC-21OR0403042 


\title{
DOCUMENT AVAILABILITY
}

Reports produced after January 1, 1996, are generally available free via US Department of Energy (DOE) SciTech Connect.

Website www.osti.gov

Reports produced before January 1, 1996, may be purchased by members of the public from the following source:

\author{
National Technical Information Service \\ 5285 Port Royal Road \\ Springfield, VA 22161 \\ Telephone 703-605-6000 (1-800-553-6847) \\ TDD 703-487-4639 \\ Fax 703-605-6900 \\ E-mail info@ntis.gov \\ Website http://classic.ntis.gov/
}

Reports are available to DOE employees, DOE contractors, Energy Technology Data Exchange representatives, and International Nuclear Information System representatives from the following source:

Office of Scientific and Technical Information

PO Box 62

Oak Ridge, TN 37831

Telephone 865-576-8401

Fax 865-576-5728

E-mail reports@osti.gov

Website http://www.osti.gov

This report was prepared as an account of work sponsored by an agency of the United States Government. Neither the United States Government nor any agency thereof, nor any of their employees, makes any warranty, express or implied, or assumes any legal liability or responsibility for the accuracy, completeness, or usefulness of any information, apparatus, product, or process disclosed, or represents that its use would not infringe privately owned rights. Reference herein to any specific commercial product, process, or service by trade name, trademark, manufacturer, or otherwise, does not necessarily constitute or imply its endorsement, recommendation, or favoring by the United States Government or any agency thereof. The views and opinions of authors expressed herein do not necessarily state or reflect those of the United States Government or any agency thereof. 

HIGH-TEMPERATURE MODERATOR APPLICATIONS

\author{
Xunxiang $\mathrm{Hu}$ \\ Hsin Wang \\ Kory Linton \\ Annabelle Le Coq \\ Kurt A. Terrani
}

June 2021

M2TC-21OR0403042

Prepared by

OAK RIDGE NATIONAL LABORATORY

Oak Ridge, TN 37831-6283

managed by

UT-BATTELLE, LLC

for the

US DEPARTMENT OF ENERGY

under contract DE-AC05-00OR22725 



\section{CONTENTS}

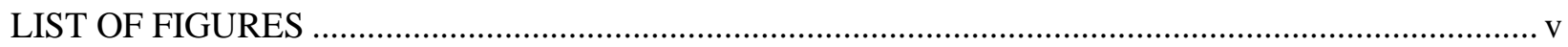

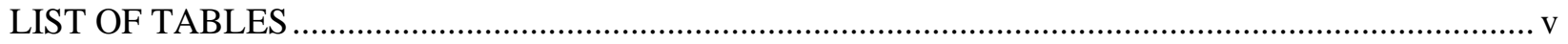

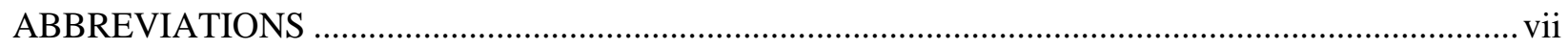

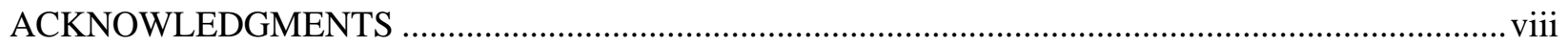

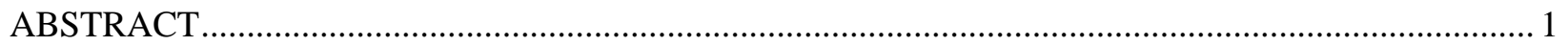

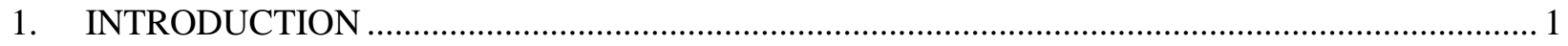

2. THERMOMECHANICAL PROPERTIES OF AS-FABRICATED YTTRIUM HYDRIDE ............... 2

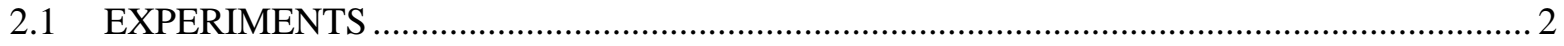

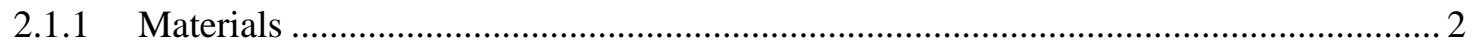

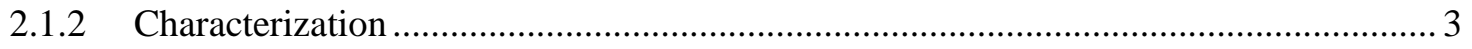

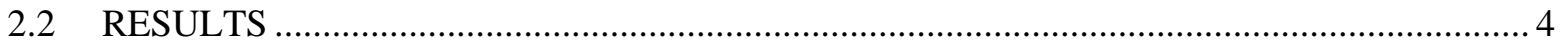

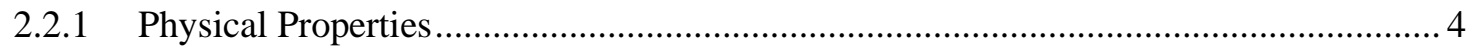

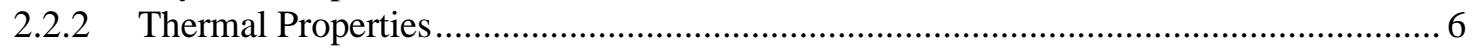

2.2.3 Mechanical Properties.................................................................................... 9

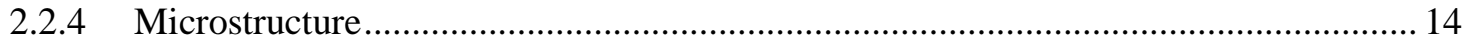

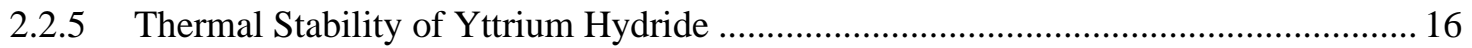

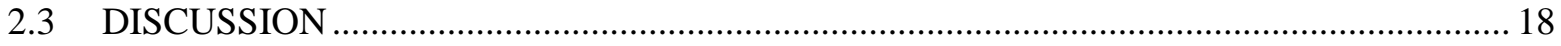

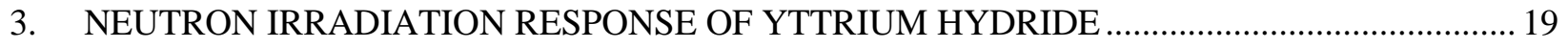

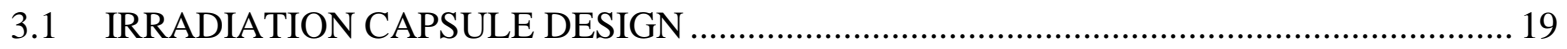

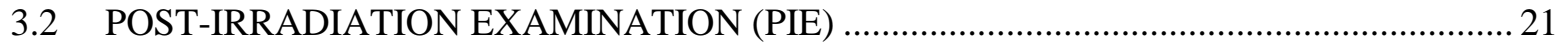

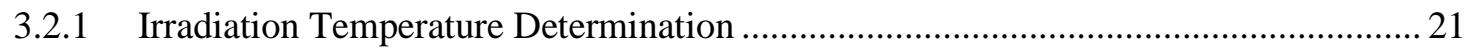

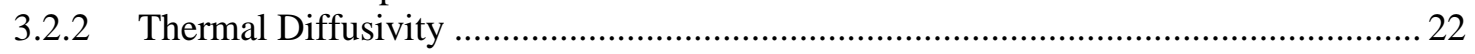

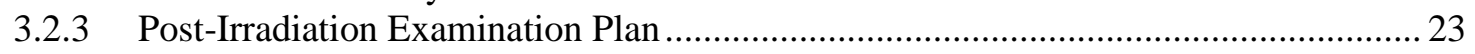

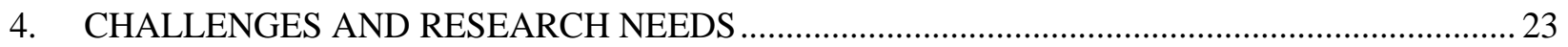

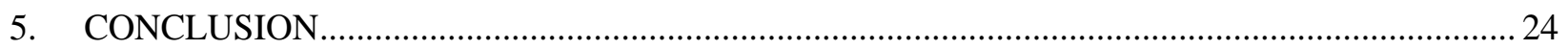

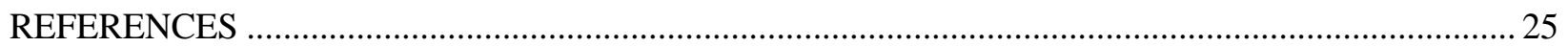





\section{LIST OF FIGURES}

Figure 1. (a) As-fabricated yttrium hydride rods; (b) an yttrium hydride rod embedded inside epoxy and the sectioned slices.

Figure 2. Density of yttrium metal and yttrium hydride at room temperature.......................................... 5

Figure 3. (a) XRD pattern of $\mathrm{YH}_{1.70}$ and Rietveld refinement fit; (b) lattice parameter and phase fraction of $\boldsymbol{\delta}-\mathrm{YH}_{\mathrm{x}}$ identified in the as-fabricated $\mathrm{YH}_{\mathrm{x}}(1.50<\mathrm{x}<2.00)$ at room temperature as determined by XRD.

Figure 4. Heat capacity, thermal diffusivity, and thermal conductivity of $\mathrm{YH}_{\mathrm{x}}(\mathrm{x}=1.88$ and 1.52) as a function of temperature. . .8

Figure 5. CTE of $\mathrm{YH}_{\mathrm{x}}$ as a function of temperature for various $\mathrm{H} / \mathrm{Y}$ ratios. . .9

Figure 6. Vickers hardness of yttrium hydride as a function of $\mathrm{H} / \mathrm{Y}$ atomic ratio. 10

Figure 7. Elastic and shear moduli of yttrium hydride as a function of $\mathrm{H} / \mathrm{Y}$ atomic ratio at room temperature together with literature data.

Figure 8. Poisson's ratio of $\mathrm{YH}_{\mathrm{x}}$ as a function of $\mathrm{H} / \mathrm{Y}$ atomic ratio at room temperature, together with literature data.

Figure 9. Plots of failure probability $\left(\mathrm{P}_{\mathrm{f}}\right)$ as a function of equibiaxial flexural strength for $\mathrm{YH}_{\mathrm{x}}$ with various hydrogen concentrations.

Figure 10. Weibull plots of the failure strength data of $\mathrm{YH}_{\mathrm{x}}(\mathrm{x}=1.00 \sim 1.87)$ determined from

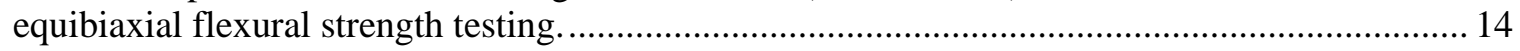

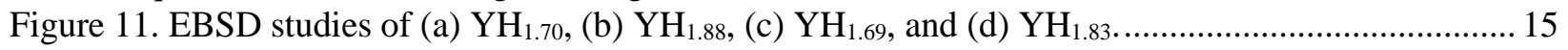

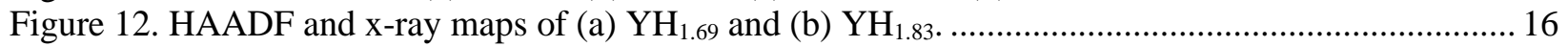

Figure 13. Hydrogen desorption flux from $\mathrm{YH}_{\mathrm{x}}(\mathrm{x}=1.76,1.84$, and 1.87) as a function of temperature measured by thermal desorption spectroscopy................................................. 17

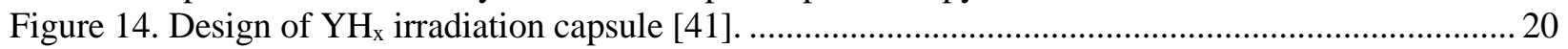

Figure 15. Samples and parts of YHT01 ............................................................................................... 20

Figure 16. Irradiation temperature determined from $\mathrm{SiC}$ thermometry compared with calculated values for different irradiation capsules.............................................................................. 22

Figure 17. Thermal diffusivity of $\mathrm{YH}_{\mathrm{x}}$ before and after neutron irradiation $\left(600\right.$ and $900^{\circ} \mathrm{C}, 0.1$ dpa).

\section{LIST OF TABLES}

Table 1. Coefficients of Eqs. (3), (4), (6), and (7) obtained through fitting the experimentally determined thermal properties 7

Table 2. Summary of Weibull statistics analysis for the equibiaxial flexural strength testing with a characteristic test volume of $1.57 \mathrm{~mm}^{3}$....

Table 3. Temperature ranges of the four hydrogen desorption stages for tested samples ........................ 17

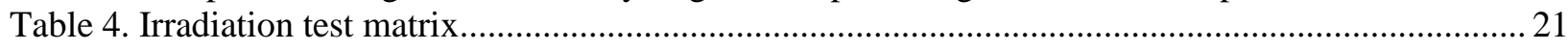





\section{ABBREVIATIONS}

$\begin{array}{ll}\text { ANP } & \text { Aircraft Nuclear Propulsion } \\ \text { ASTM } & \text { American Society for Testing and Materials } \\ \text { CTE } & \text { coefficient of linear thermal expansion } \\ \text { DH } & \text { direct hydride } \\ \text { DFT } & \text { density functional theory } \\ \text { DOE } & \text { US Department of Energy } \\ \text { DSC } & \text { differential scanning calorimeter } \\ \text { EBSD } & \text { electron backscatter diffraction } \\ \text { EDS } & \text { energy dispersive spectroscopy } \\ \text { FIB } & \text { focus ion beam } \\ \text { FCC } & \text { face-centered cubic } \\ \text { HAADF } & \text { high-angle annular dark-field } \\ \text { HCP } & \text { hexagonal closest packed } \\ \text { HFIR } & \text { High Flux Isotope Reactor } \\ \text { LaB } & \text { Lanthanum hexaboride } \\ \text { LAMDA } & \text { Low Activation Materials Development and Analysis Laboratory } \\ \text { LFA } & \text { laser flash technique } \\ \text { NI } & \text { nanoindentation } \\ \text { ORNL } & \text { Oak Ridge National Laboratory } \\ \text { PCT } & \text { pressure-composition-temperature map } \\ \text { PIE } & \text { post-irradiation examination } \\ \text { RUS } & \text { resonant ultrasound spectroscopy } \\ \text { SEM } & \text { scanning electron microscope } \\ \text { SiC } & \text { silicon carbide } \\ \text { SM } & \text { sintered monoliths } \\ \text { SNAP } & \text { Systems Nuclear Auxiliary Power } \\ \text { SRM } & \text { standard reference material } \\ \text { TCR } & \text { Transformational Challenge Reactor } \\ \text { TDS } & \text { thermal desorption spectroscopy } \\ \text { TM } & \text { thermometry } \\ \text { TRIGA } & \text { Training, Research, Isotopes, General Atomic } \\ \text { X/FEG } & \text { extreme field emission gun } \\ \text { XRD } & \text { x-ray diffraction } \\ \text { YH } & \text { yttrium hydride } \\ \text { ZrH } & \text { zirconium hydride } \\ & \end{array}$




\section{ACKNOWLEDGMENTS}

This research was supported by the Transformational Challenge Reactor program supported by the US Department of Energy Office of Nuclear Energy. The report was authored by UT-Battelle under Contract No. DE-AC05-00OR22725 with the DOE.

The authors thank David Bryant, the hot cell and LAMDA staff for their significant contribution to the neutron irradiation campaign of yttrium hydride. The authors also thank Ben Garrison at ORNL for assistance with the fabrication of yttrium hydride and his technical review of the report. We thank Dr. T.S. Byun for the technical review. 



\begin{abstract}
Yttrium hydride is an optimal choice for a high-temperature moderator material in advanced thermal neutron spectrum reactors that require small core volumes. A complete database of the thermomechanical properties of yttrium hydride is not yet available, although it is much needed to understand and predict the moderator performance during service in reactors. This milestone report presents the properties of unirradiated bulk yttrium hydride as a function of hydrogen concentration-including density, crystal structure, specific heat capacity, thermal diffusivity, thermal conductivity, hardness, elastic/shear moduli, Poisson's ratio, fracture strength, microstructure, and thermal stability. This information provides a baseline measurement for the subsequent neutron irradiation response study of yttrium hydride. The recommended empirical treatment of the data is suggested. In addition, other properties (i.e., hydrogen retention, thermal hydrogen migration, and irradiation response) requiring investigation are discussed. Also included are the Preliminary post-irradiation examination (PIE) data of yttrium hydride irradiated at 600 and $900^{\circ} \mathrm{C}$ to $0.1 \mathrm{dpa}$ in the High Flux Isotope Reactor (HFIR). The thermophysical properties have insignificant change following this low dpa irradiation for both irradiation temperatures.
\end{abstract}

\title{
1. INTRODUCTION
}

Given its equivalent mass to neutron, its low neutron absorption cross section, and its high neutron scattering cross section, hydrogen efficiently slows down fast neutrons. Therefore, hydrogen-bearing materials such as water and metal hydrides have been widely selected as candidates for moderators in various thermal nuclear reactors $[1,2]$. The use of water as a high-temperature moderator material has been restricted by the requirement for extremely high pressure. In contrast, metal hydrides are uniquely suitable for use as high-temperature moderators $[2,3]$. For example, because of the neutron transparency of zirconium, as well as the outstanding moderating ratio of hydrogen, zirconium hydride was employed as the moderator material in multiple historical reactors such as the Systems Nuclear Auxiliary Power (SNAP) Program [4], the Training, Research, Isotopes, General Atomic (TRIGA) research reactors [5], and nuclear thermal propulsion reactors [6]. Compared with zirconium hydride, yttrium hydride $\left(\mathrm{YH}_{\mathrm{x}}\right)$ exhibits superior thermal stability and retains a higher hydrogen content at elevated temperatures (above $1,143 \mathrm{~K}$ ), thus offering unique advantages as a moderator for high-temperature thermal neutron spectrum reactors [3, 7]. However, its broad adoption has been prevented by (1) the unavailability of high-purity yttrium as an industrial metal, and (2) by its prohibitive cost during the first nuclear era. This situation has improved significantly since the late $1970 \mathrm{~s}$. $\mathrm{YH}_{\mathrm{x}}$ is now being actively developed under various US Department of Energy (DOE) and National Aeronautics and Space Administration (NASA) programs to serve as the moderator for microreactors and small modular reactors [8]. DOE's Office of Nuclear Energy launched the Transformational Challenge Reactor (TCR) program in 2019 to design and build an additively manufactured microreactor at Oak Ridge National Laboratory (ORNL). This reactor will use $\mathrm{YH}_{\mathrm{x}}$ as the moderator material [9]. Very limited efforts have been committed to the fabrication of $\mathrm{YH}_{\mathrm{x}}$ and its subsequent characterization in response to the need to establish a complete database of the thermomechanical properties of $\mathrm{YH}_{\mathrm{x}}$. Preliminary evaluations of the thermomechanical properties of $\mathrm{YH}_{\mathrm{x}}$ were carried out in the 1960s and are available in Mueller et al. [3]. Since the high-purity yttrium has become available, Ito et al. [10] report the thermal properties (i.e., specific heat capacity, thermal diffusivity, and thermal conductivities) of three bulk $\mathrm{YH}_{\mathrm{x}}$ samples $\left(\mathrm{YH}_{1.72}, \mathrm{YH}_{1.86}\right.$, and $\left.\mathrm{YH}_{1.90}\right)$ in the temperature range from 300 to $773 \mathrm{~K}$. Setoyama et al. from the same research group [11] investigated the Vickers hardness and Young's modulus of $\mathrm{YH}_{\mathrm{x}}(1.7<\mathrm{x}<2.0)$ at room temperature. In addition to the bulk $\mathrm{YH}_{\mathrm{x}}$ fabricated through direct hydriding, Shivprasad et al. [12] report the elastic moduli of high-density sintered monoliths of yttrium dihydride, as well as the thermophysical properties [13]. Most literature reports the properties of $\mathrm{YH}_{\mathrm{x}}$ with $\mathrm{H} / \mathrm{Y}$ atomic ratios greater than 1.90, as there is a prevailing impression that more hydrogen is preferred. In fact, it is not always correct that the use of stoichiometric yttrium dihydride gives rise to the most optimal reactor design, as it might result in over-moderating neutrons, 
and it requires higher equilibrium hydrogen partial pressure to maintain that stoichiometry. Furthermore, fabrication of $\mathrm{YH}_{\mathrm{x}}$ with higher hydrogen concentrations is more challenging, as the volume expansion is more significant [14]. Depending on the specific reactor design need, the geometries and the hydrogen concentrations of $\mathrm{YH}_{\mathrm{x}}$ would vary. Therefore, knowledge regarding the hydrogen content dependence of the properties of $\mathrm{YH}_{\mathrm{x}}$ is necessary. The study presented in this paper aims to complement other ongoing efforts in providing a reproducible and complete database of properties to facilitate the deployment of $\mathrm{YH}_{\mathrm{x}}$ as a high-temperature moderator material. The activities under the TCR program are dedicated to developing a complete database of bulk $\mathrm{YH}_{\mathrm{x}}$ fabricated via the direct interaction of hydrogen and ultrahigh-purity yttrium metal at elevated temperatures. This paper reports the detailed characterization of crack-free bulk $\mathrm{YH}_{\mathrm{x}}$ with respect to the microstructures and thermomechanical properties. Other important properties of $\mathrm{YH}_{\mathrm{x}}$ that have not been extensively studied will also be discussed.

\section{THERMOMECHANICAL PROPERTIES OF AS-FABRICATED YTTRIUM HYDRIDE}

\subsection{EXPERIMENTS}

\subsubsection{Materials}

Crack-free bulk $\mathrm{YH}_{\mathrm{x}}$ samples with various $\mathrm{H} / \mathrm{Y}$ atomic ratios were fabricated through the direct interaction of ultra-high-purity metallic yttrium (nominal 99.99\%) and hydrogen at elevated temperatures. The hydriding process was informed by the well-established thermodynamic property of the Y-H binary system. A fully programmable metal hydriding system with continuous hydrogen partial pressure and flow control coordinated with precise temperature control was designed and constructed at ORNL. Detailed information is available in $\mathrm{Hu}$ et al. [14] .

$\mathrm{YH}_{\mathrm{x}}$ rods $(10 \mathrm{~mm}$ in diameter, $15 \mathrm{~mm}$ in height, approximately $5.4 \mathrm{~g}$ ) were fabricated with $\mathrm{H} / \mathrm{Y}$ atomic ratios ranging from 1.52 to 1.88 . The hydrogen concentration was determined by the weight gain of the samples before and after hydriding. Figure 1 contains a photo of five as-fabricated hydride rods. These hydride rods were embedded inside epoxy and were sectioned into disks approximately $1 \mathrm{~mm}$ thick using a slow-speed diamond saw, for use in further thermomechanical property measurements. 
(a)

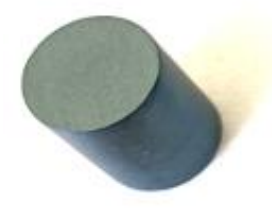

YHR-1

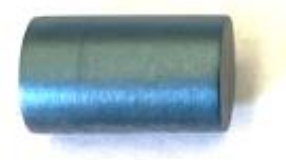

YHR-2

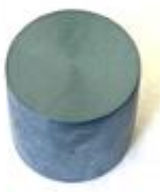

YHR-3

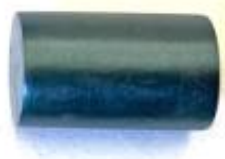

YHR-4

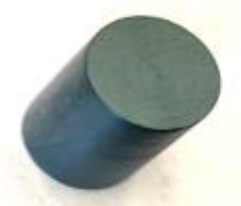

YHR-5

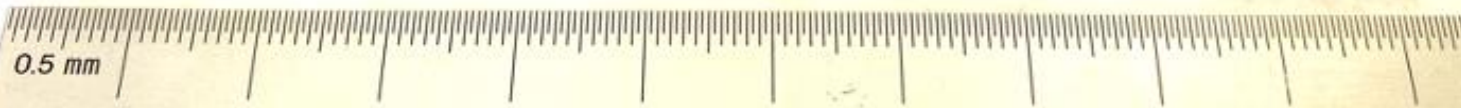
$\begin{array}{lllllllllll}10 & 20 & 30 & 40 & 50 & 60 & 70 & 80 & 90 & 100 & 110\end{array}$

(b)
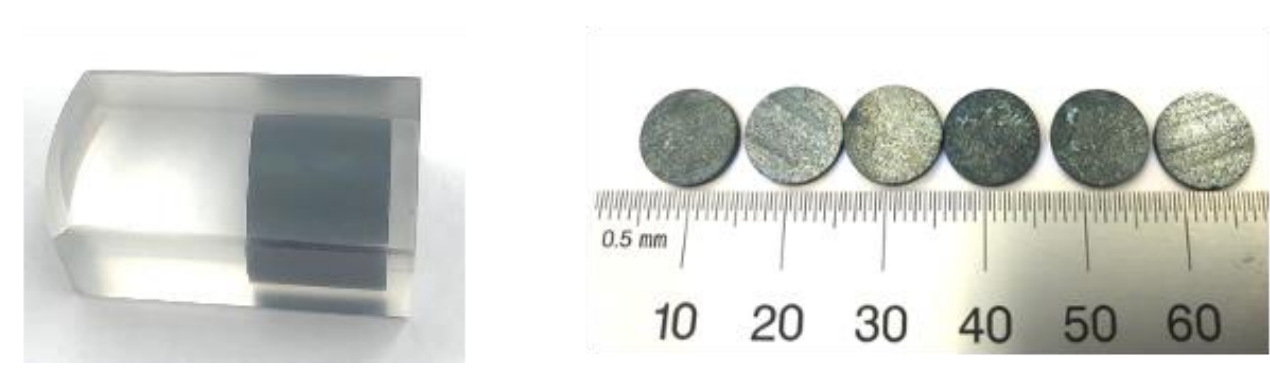

Figure 1. (a) As-fabricated yttrium hydride rods; (b) an yttrium hydride rod embedded inside epoxy and the sectioned slices.

\subsubsection{Characterization}

The density of the as-fabricated $\mathrm{YH}_{\mathrm{x}}$ was measured using a Mettler Toledo XS105 microbalance. X-ray diffraction (XRD) analysis was used to confirm the phases present in the fabricated hydride samples. XRD samples were prepared by depositing $\mathrm{YH}_{\mathrm{x}}$ powder on a zero-background (for $2 \theta<120^{\circ}$ ) silicon dioxide single-crystal sample holder. Samples were also mixed with lanthanum hexaboride $\left(\mathrm{LaB}_{6}\right)$ powder (NIST SRM660b), which served as an internal standard during pattern refinement. XRD patterns were obtained using a Bruker D2 Phaser benchtop x-ray diffractometer of $0.30 \mathrm{~kW}$ with $\mathrm{Cu} \mathrm{K} \alpha$ radiation. Rietveld refinement was performed on the experimental patterns using the General Structure Analysis System [15].

For the thermal properties, specific heat capacity was measured according to American Society for Testing Materials (ASTM) E1269 [16] at $10^{\circ} \mathrm{C} / \mathrm{min}$ using a Netzsch differential scanning calorimeter (DSC) 404C. Temperatures ranged from room temperature to $773 \mathrm{~K}$ for $\mathrm{YH}_{\mathrm{x}}$, with $x=1.88$, and from room temperature to $973 \mathrm{~K}$ for $\mathrm{YH}_{\mathrm{x}}$, with $x=1.52$. Each sample underwent two full heating and cooling DSC runs to confirm reproducibility. Platinum pans and lids were used during the DSC runs. Sapphire was used as a standard reference material. Thermal diffusivity measurements were performed according to ASTM E1461 [17] using a Netzsch LFA 457 laser flash system. The testing temperature range was identical to that of the specific heat capacity measurement. The testing was performed under argon purge gas at $100 \mathrm{~mL} / \mathrm{min}$. The diffusivity values were calculated based on the sample thickness and the temperature rise curve after each laser pulse using the Cowan method with pulse width correction [18, 19]. Three measurements were performed at each temperature set point for every sample, and the average values with the standard deviation are reported. The coefficient of linear thermal expansion (CTE) was measured using a Theta Dilatronic IX differential dilatometer, which is a horizontal dual pushrod dilatometer. The $\mathrm{YH}_{\mathrm{x}}$ samples were $6 \mathrm{~mm}$ diameter cylindrical rods $25 \mathrm{~mm}$ long. The temperature range was from 373 to $973 \mathrm{~K}$. A heating/cooling rate of $3 \mathrm{~K} / \mathrm{min}$ was used. Each sample was measured twice to confirm reproducibility, and a sapphire standard was used as a reference. Before each run, the vacuum- 
tight dilatometer was pumped down and backfilled with helium three times, and then it was pumped down a final time to below 200 mTorr. During the run, titanium-gettered helium flowed through the system at $15 \mathrm{sccm}$.

Vickers hardness measurement was carried out using the Buhler Tukon3100. The applied load was $200 \mathrm{~g}$, and the dwell time for the indentation was $15 \mathrm{~s}$. Ten measurements were performed on each sample to obtain good statistics. The equibiaxial ring-on-ring flexural strength test method was used to measure the fracture strength of $\mathrm{YH}_{\mathrm{x}}$ thin disk specimens, following the ASTM standard test method C1499-09 [20]. An MTS Insight Electromechanical Testing System with a $2 \mathrm{kN}$ loading capacity was used to perform the equibiaxial testing.

Thermal hydrogen desorption measurements were performed using the thermal desorption system. The $\mathrm{YH}_{\mathrm{x}}$ samples (6 and $0.5 \mathrm{~mm}$ in diameter) were heated to $1,223 \mathrm{~K}$ at a constant ramping rate of $0.5 \mathrm{~K} / \mathrm{s}$. The sample temperature was monitored using a K-type thermocouple thermometer located inside the quartz tube $\sim 1 \mathrm{~mm}$ away from the tested sample. The baseline vacuum level of this system was $6 \times 10^{-8}$ torr. The desorbed hydrogen gas was recorded by using a quadruple mass spectrometer. The hydrogen signal recorded during the measurement was calibrated using a Vacuum Technology Incorporated standard hydrogen leak with a leak rate of $1 \times 10^{-12} \mathrm{~mol} / \mathrm{s}$. More information for this high vacuum system is available in two papers by Hu et al. [21, 22].

Microstructural characterization via focused ion beam/scanning electron microscopy (FIB/SEM) and scanning/transmission electron microscopy (S/TEM) was performed to analyze the as-fabricated $\mathrm{YH}_{\mathrm{x}}$. The sample surface morphology and orientation were characterized using a TESCAN MIRA3 SEM operated at $20 \mathrm{kV}$. Electron-transparent TEM foils were prepared using an FIB/SEM (FEI Quanta 3D Dual Beam or FEI Versa 3D Dual Beam FIB/SEM) operated at $30 \mathrm{kV}$ and $16 \mathrm{kV}$ for initial milling followed by $8 \mathrm{kV}$ and $5 \mathrm{kV}$ for final thinning. A final $2 \mathrm{kV}$ low-current polish was used to minimize any FIB-induced damages. The samples were then transferred to a Fischione Model 1040 Nanomill to improve the quality of the foils using $900 \mathrm{~V}$ argon ions. TEM examination was performed in an FEI Talos F200X S/TEM (200 keV, Schottky-emission) equipped with an extreme field emission gun (X/FEG) high-brightness field emission source, a SuperX four-detector x-ray energy dispersive spectroscopy (EDS) system, bright-field detectors, and three annular dark-field detectors.

\subsection{RESULTS}

\subsubsection{Physical Properties}

Figure 2 shows the densities of the fabricated $\mathrm{YH}_{\mathrm{x}}$ samples, as well as the metal yttrium at room temperature. The addition of hydrogen atoms into yttrium metal results in a decrease in density. The density of the hydride decreases slightly with the increasing $\mathrm{H} / \mathrm{Y}$ atomic ratio in the range from 1.50 to 1.90, exhibiting an approximate linear correlation,

$$
\rho=4.37-5.82 \times 10^{-2} \mathrm{C} \quad\left[\frac{\mathrm{g}}{\mathrm{cm}^{3}}\right],
$$

where $\rho$ is density, and $C$ is the $\mathrm{H} / \mathrm{Y}$ atomic ratio.

The decrease in density indicates a 4.5 5.0\% volume expansion when a hydride is formed as the alphayttrium metal absorbs hydrogen. 


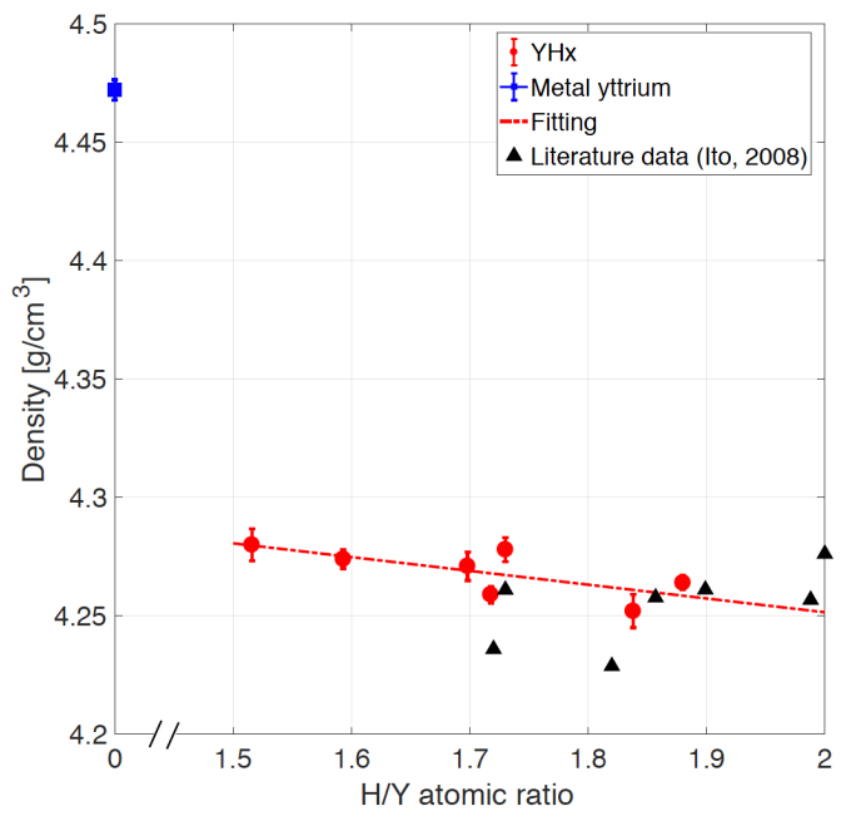

Figure 2. Density of yttrium metal and yttrium hydride at room temperature.

The dashed line is included to indicate trend.

A typical XRD pattern along with Rietveld refinement fit of $\mathrm{YH}_{\mathrm{x}}$ at room temperature $\left(\mathrm{YH}_{1.70}\right)$ is shown in Figure 3(a). The $\chi^{2}$ values of Rietveld refinement fit for all samples are in the range of 1.7 3.8, indicating the sufficient goodness of the fit. XRD analysis indicates that only $\alpha$-yttrium ( $\mathrm{P}_{3} / \mathrm{mmc}$, hexagonal-closest-packed crystal structure) and $\delta$ - $\mathrm{YH}_{2}(\mathrm{Fm} \overline{3} \mathrm{~m}$, face-centered-cubic structure [FCC]) are present. The absence of oxide and other phases verifies the clean environment of the hydriding system and further strengthens the rationale for using the weight change method to determine the hydrogen concentration [14]. Figure 3(b) indicates that the lattice parameters determined from the Rietveld refinement fit fall in the range of $0.5200 \sim 0.5207 \mathrm{~nm}$ in the present study, which agrees well with the reported data [23, 24]. The linear correlation between the lattice parameter and the hydrogen concentration is not as obvious as that shown in Setoyama et al. [11]. The weight fraction of $\delta-\mathrm{YH}_{2}$ increases as the hydrogen concentration in the studied $\mathrm{YH}_{\mathrm{x}}$ increases. When the $\mathrm{H} / \mathrm{Y}$ atomic ratio approaches 1.90 , the hydride samples are almost in a single phase with less than $1 \% \alpha$-yttrium, which is within the uncertainty of the XRD analysis. An empirical correlation between the fraction of $\delta$ - $\mathrm{YH}_{2}$ and the hydrogen concentration is:

$$
f_{\delta-Y H_{2}}[\%]=53 \times C-1.05
$$

where $C$ is the $\mathrm{H} / \mathrm{Y}$ atomic ratio of $\mathrm{YH}_{\mathrm{x}}(1.50<C<1.90)$. 
(a)

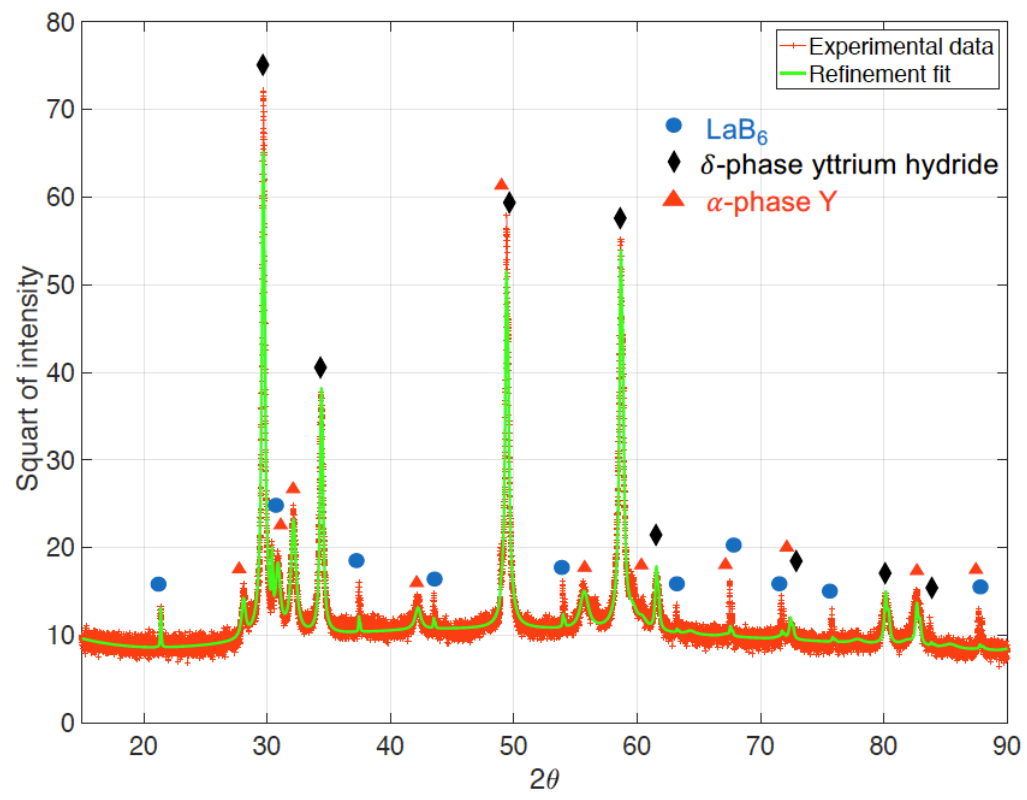

(b)

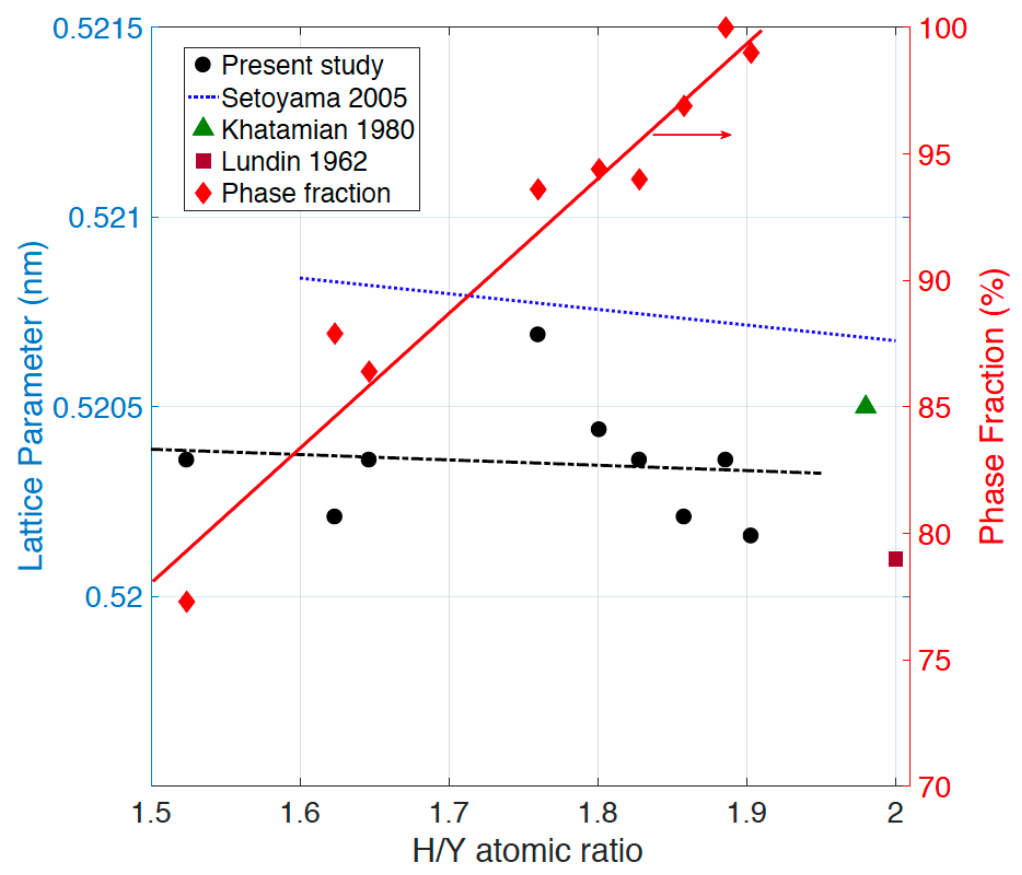

Figure 3. (a) XRD pattern of $\mathrm{YH}_{1.70}$ and Rietveld refinement fit; (b) lattice parameter and phase fraction of $\delta$ $\mathrm{YH}_{\mathrm{x}}$ identified in the as-fabricated $\mathrm{YH}_{\mathrm{x}}(1.50<\mathrm{x}<2.00)$ at room temperature as determined by XRD.

\subsubsection{Thermal Properties}

DSC measurements were carried out to determine the specific heat capacity of $\mathrm{YH}_{\mathrm{x}} . \mathrm{A} \lambda$-type $C_{\mathrm{p}}$ was observed for all tested samples, indicating an endothermic second-order transition associated with the hydrogen order-disorder transition, as shown in Figure 4. The second-order transition temperature increases with decreasing hydrogen concentration, as shown in Trofimov et al. [25]. A higher specific heat capacity was found for $\mathrm{YH}_{\mathrm{x}}$ with a larger $\mathrm{H} / \mathrm{Y}$ atomic ratio before the occurrence of the transition. 
However, the measured specific heat capacity of $\mathrm{YH}_{\mathrm{x}}$ with an $\mathrm{H} / \mathrm{Y}$ ratio of $1.52 \sim 1.88$ falls in a narrow regime, $\pm 0.05 \mathrm{~J} /(\mathrm{g} \cdot K)$. The dependence of the hydrogen concentration becomes negligible beyond the transition, and the measured specific heat capacities fall onto the same line. The specific heat capacity of $\mathrm{YH}_{1.52}$ and $\mathrm{YH}_{1.88}$ is expressed in the following equation by fitting the experimental data:

$$
C_{p}[J /(g \cdot K)]=\left\{\begin{array}{lr}
a+b \cdot T+c \cdot T^{2} & (T<\text { tansition } T) \\
a \cdot \exp (b \cdot T)+c \cdot \exp (d \cdot T) & \left(\text { For } Y H_{1.88,}, T>\text { tansition } T\right) \\
a+b \cdot \cos (c \cdot T)+d \cdot \sin (c \cdot T) & \left(\text { For } Y H_{1.52,}, T>\text { tansition } T\right)
\end{array}\right.
$$

The coefficients of Eq. (3) are provided in Table 1.

The measured thermal diffusivity of $\mathrm{YH}_{\mathrm{x}}(1.50<x<1.90)$ using the laser flash method exhibits behavior similar to the specific heat capacity with respect to the hydrogen concentration dependence and the second-order transition, as manifested by the slope change and shown in Figure 4. The continuous decline in thermal diffusivity is characteristic of ceramics with poor electronic conductivity and is dominated by Umklapp (phonon-phonon) scattering. It is evident that the measured thermal diffusivity of the studied $\mathrm{YH}_{\mathrm{x}}$ can be classified into two groups: $\mathrm{YH}_{\mathrm{x}}$ with $\mathrm{H} / \mathrm{Y}>1.70$ and $\mathrm{H} / \mathrm{Y}<1.60$. The thermal diffusivity of $\mathrm{YH}_{\mathrm{x}}$ with $\mathrm{H} / \mathrm{Y}>1.70$ is roughly $30 \%$ higher than that of $\mathrm{YH}_{\mathrm{x}}$ with $\mathrm{H} / \mathrm{Y}<1.60$, whereas the variation in each group is within a small range of $\pm 0.5 \mathrm{~cm}^{2} / \mathrm{s}$. A linear correlation between $\alpha^{-1}$ and T exists for the phonon conductor [26],

$$
\alpha^{-1}=a \cdot T+c
$$

where $\alpha$ is in the units of $\mathrm{cm}^{2} / \mathrm{s}$ and is related to the temperature-dependent phonon-phonon scattering processes (intrinsic lattice diffusivity), and $c$ is related to the temperature-independent phonon scattering processes such as impurities, defects, and grain boundaries. The coefficients of these equations are given in Table 1.

Table 1. Coefficients of Eqs. (3), (4), (6), and (7) obtained through fitting the experimentally determined thermal properties

\begin{tabular}{|c|c|c|c|c|c|c|}
\hline $\begin{array}{c}\text { H/Y } \\
\text { atomic } \\
\text { ratio }\end{array}$ & $\begin{array}{c}\text { Thermal } \\
\text { properties }\end{array}$ & $\begin{array}{c}\text { Temperature } \\
\text { range (K) }\end{array}$ & $\mathbf{a}$ & $\mathbf{b}$ & $\mathbf{c}$ & $\mathbf{d}$ \\
\hline \multirow{2}{*}{ N/A } & $\begin{array}{c}\text { Second-order } \\
\text { transition } \\
\text { temperature }\end{array}$ & $300-973$ & $-4.64 \times 10^{-13}$ & 17.91 & 1321 & -0.24 \\
\hline \multirow{2}{*}{1.52} & $\begin{array}{c}\text { Specific heat } \\
\text { capacity }\end{array}$ & $300-920$ & 0.44 & $-4.25 \times 10^{-4}$ & $1.25 \times 10^{-6}$ & N/A \\
\cline { 2 - 7 } & $\begin{array}{c}\text { Thermal } \\
\text { diffusivity }\end{array}$ & $300-973$ & 0.035 & N/A & -10.7 & N/A \\
\hline \multirow{2}{*}{1.61} & CTE & $300-973$ & 4.64 & $6.74 \times 10^{-3}$ & $1.32 \times 10^{-5}$ & $-1.06 \times 10^{-8}$ \\
\hline \multirow{2}{*}{1.85} & CTE & $300-900$ & -0.29 & 0.037 & $-4.88 \times 10^{-5}$ & $3.16 \times 10^{-8}$ \\
\cline { 3 - 7 } & & $900-973$ & -380.5 & 1.26 & $-1.33 \times 10^{-3}$ & $4.68 \times 10^{-7}$ \\
\hline \multirow{2}{*}{1.88} & \multirow{2}{*}{$\begin{array}{c}\text { Specific heat } \\
\text { capacity }\end{array}$} & $300-648$ & $5.35 \times 10^{-2}$ & $1.20 \times 10^{-3}$ & $-2.26 \times 10^{-7}$ & N/A \\
\cline { 2 - 7 } & Thermal & $648-823$ & $2.23 \times 10^{10}$ & $-4.09 \times 10^{-2}$ & 0.35 & $9.88 \times 10^{-4}$ \\
\hline & diffusivity & $300-823$ & 0.016 & N/A & -2.46 & N/A \\
\hline
\end{tabular}


The thermal conductivity, $k$, is the product of density, $\rho$, heat capacity, $C_{p}$, and thermal diffusivity, $\alpha$, as shown in Eq. (5):

$$
k=\alpha \rho C_{p} .
$$

It is evident that the thermal conductivity decreased with increasing temperature and increased with increasing hydrogen concentration. The calculated thermal conductivity showed acceptable agreement with the literature data.

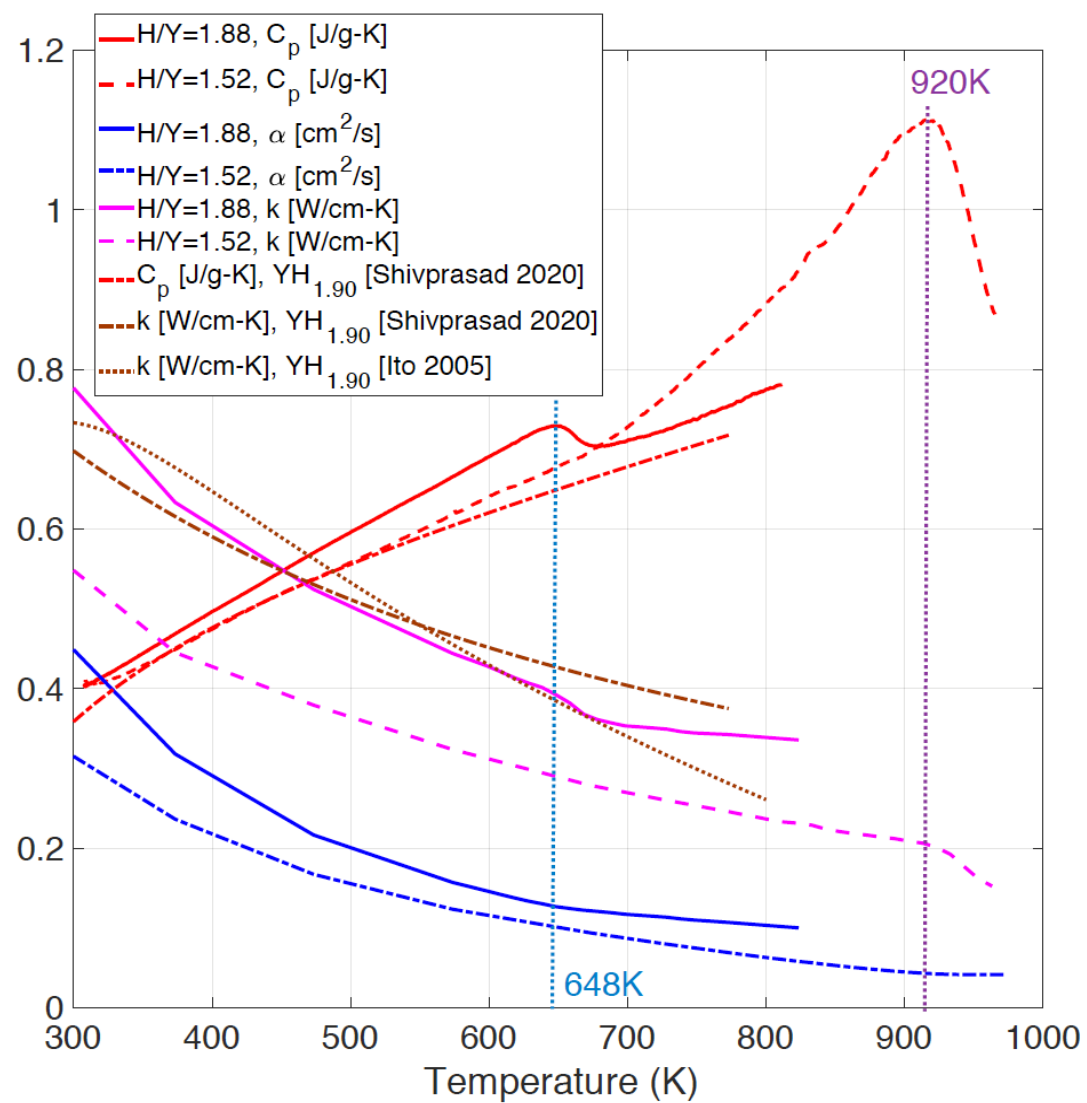

Figure 4. Heat capacity, thermal diffusivity, and thermal conductivity of $\mathrm{YH}_{\mathrm{x}}(\mathrm{x}=1.88$ and 1.52$)$ as a function of temperature. The second-order transition temperatures are labeled. Note that Shivprasad's data are measured from sintered yttrium hydride.

The CTE of $\mathrm{YH}_{\mathrm{x}}(1.72<\mathrm{x}<1.93)$ has been reported to vary from $4.0 \times 10^{-6}$ to $16 \times 10^{-6} / \mathrm{K}$ in the temperature range of 300-800 K [27]. In this work, dilatometer measurements yielded similar results, as shown in Figure 5. Note that the CTE reported in Shivprasad et al. [13] was determined by analyzing the lattice parameter of sintered monolithic yttrium dihydride as a function of temperature, which exhibited higher values. The linear thermal expansion coefficient of $\mathrm{YH}_{\mathrm{x}}(1.60<\mathrm{x}<1.95)$ varies in the range of $8 \times 10^{-6}$ to $16.5 \times 10^{-6} / \mathrm{K}$ in the temperature regime of $400-973 \mathrm{~K}$. The second-order transition identified in both the thermal diffusivity and heat capacity measurements also leads to a slope change in the measured linear thermal expansion coefficient. The hydrogen dependence in the temperature regime before transition is limited. Beyond the transition temperature, $\mathrm{YH}_{\mathrm{x}}$ with a higher hydrogen concentration has a smaller CTE. The second-order transition temperatures identified from these measured thermal properties were selfconsistent. More details on the thermal properties of $\mathrm{YH}_{\mathrm{x}}$ can be found in Trofimov et al. [25]. The 
empirical expressions for the linear thermal expansion coefficient of $\mathrm{YH}_{1.85}$ and $\mathrm{YH}_{1.61}$ were determined by fitting the experimental data as given in Eq. (6):

$$
\text { CTE }\left[10^{-6} K^{-1}\right]=a+b \cdot T+c \cdot T^{2}+d \cdot T^{3}
$$

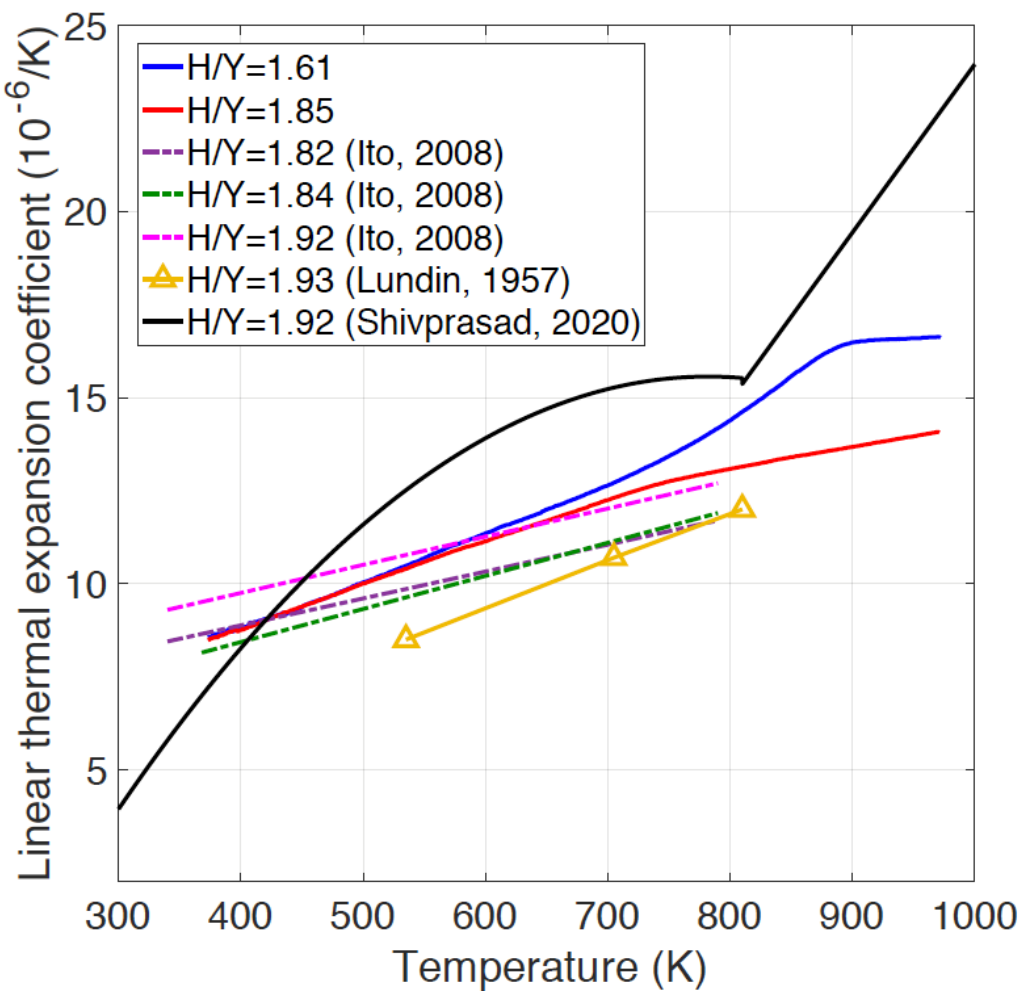

Figure 5. CTE of $\mathrm{YH}_{\mathrm{x}}$ as a function of temperature for various $\mathrm{H} / \mathrm{Y}$ ratios.

As indicated in all thermal property measurements, a clear correlation between the second-order transition temperature and the $\mathrm{H} / \mathrm{Y}$ atomic ratio exists. It is expressed in the form of

$$
T_{\text {transition }}=a \cdot \exp (b \cdot T)+c \cdot \exp (d \cdot T) .
$$

The coefficients of this equation are listed in Table 1 above. It is emphasized here that the underlying mechanisms governing the second-order endothermic transition have not been fully revealed, although it has been deduced that this transition is associated with the hydrogen order-disorder transition.

\subsubsection{Mechanical Properties}

\subsubsection{Vickers hardness}

The Vickers hardness values obtained for $\mathrm{YH}_{\mathrm{x}}$ are shown in Figure 6, along with the available literature data. The results show that a higher hydrogen concentration results in greater hardness within a relatively narrow regime of 1.8 2.5 GPa. The linear correlation is expressed as

$$
H[G P a]=0.89 \times C+0.65,
$$

where $C$ is the $\mathrm{H} / \mathrm{Y}$ atomic ratio of $\mathrm{YH}_{\mathrm{x}}$. 
The Setoyama's hardness values [11] are higher than the presented values and scattering within a large range of 3 4.5 GPa. Since no detailed information for the tested hydride was reported in Setoyama et al. [11], the cause for the discrepancy in Figure 6 was not identified. In addition, the hardness reported by Parker [26] fell onto the trajectory of the hardness data obtained in this analysis.

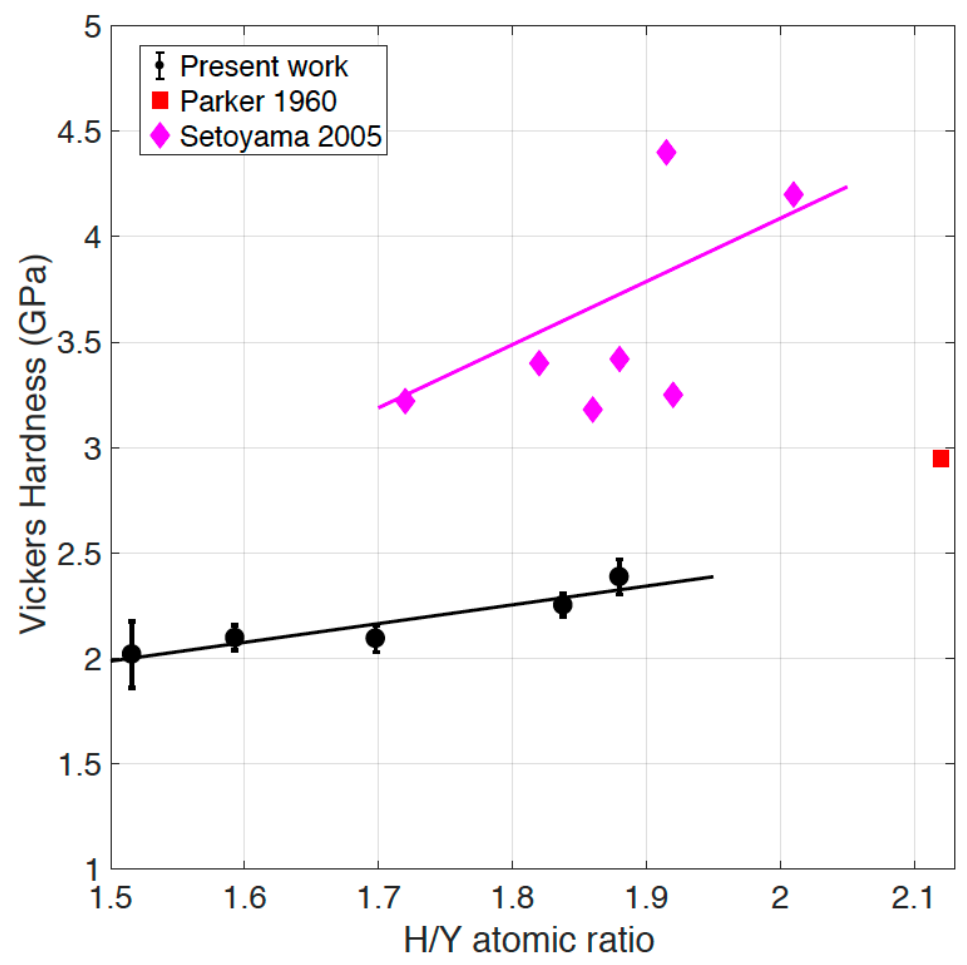

Figure 6. Vickers hardness of yttrium hydride as a function of $\mathrm{H} / \mathrm{Y}$ atomic ratio.

\subsubsection{Elastic Properties}

The $\mathrm{YH}_{\mathrm{x}}$ rods (10 $\mathrm{mm}$ in diameter and $15 \mathrm{~mm}$ in height), as shown in Figure 1(a), were analyzed via resonant ultrasound spectroscopy (RUS) to determine the elastic and shear moduli ( $E$ and $G$ ), as well as the Poisson's ratio $(v)$, as a function of H/Y atomic ratio. RUS measures the mechanical resonances of a freely vibrating solid, which depend on the elasticity, size, and shape of the object. An iteration procedure was performed to fit the measured resonance frequencies with the calculated frequencies as determined with finite element simulations, which were informed with the basic mechanical properties of the studied material [28]. Monolithic $\mathrm{YH}_{\mathrm{x}}$ rods that were analyzed using RUS were assumed to be polycrystalline isotropic.

The elastic and shear moduli of $\mathrm{YH}_{\mathrm{x}}$ as a function of hydrogen concentration at room temperature are presented in Figure 7, together with available literature data [11, 12, 27, 29-31]. It is evident that both elastic and shear moduli obtained in the current study are linearly proportional to the H/Y atomic ratio. The elastic moduli scatter in the range of $125 \sim 140 \mathrm{GPa}$ when the $\mathrm{H} / \mathrm{Y}$ atomic ratio is greater than 1.80 . In the same hydrogen concentration regime, the available shear modulus data fall into a range from 47 to 57 $\mathrm{GPa}$. In contrast, no obvious hydrogen concentration dependence was observed for the Poisson's ratio, as shown in Figure 8. The Poisson's ratio of $\mathrm{YH}_{\mathrm{x}}$ ranges from 0.21 to 0.26 for $1.50<\mathrm{H} / \mathrm{Y}<2.02$. The expressions of the elastic and shear moduli are 


$$
\begin{aligned}
& E[G P a]=48.43 \times C+43.01, \\
& G[G P a]=20.11 \times C+16.66,
\end{aligned}
$$

where $C$ is the $\mathrm{H} / \mathrm{Y}$ atomic ratio of $\mathrm{YH}_{\mathrm{x}}$. The elastic modulus may also be calculated from $E=2 G(1+v)$ if the material is isotropic. The calculated $\mathrm{E}$ values (omitted here) are within $<1 \%$ of what is determined from Eq. (9), further attesting to the isotropic nature of direct-hydriding-derived $\mathrm{YH}_{\mathrm{x}}$.

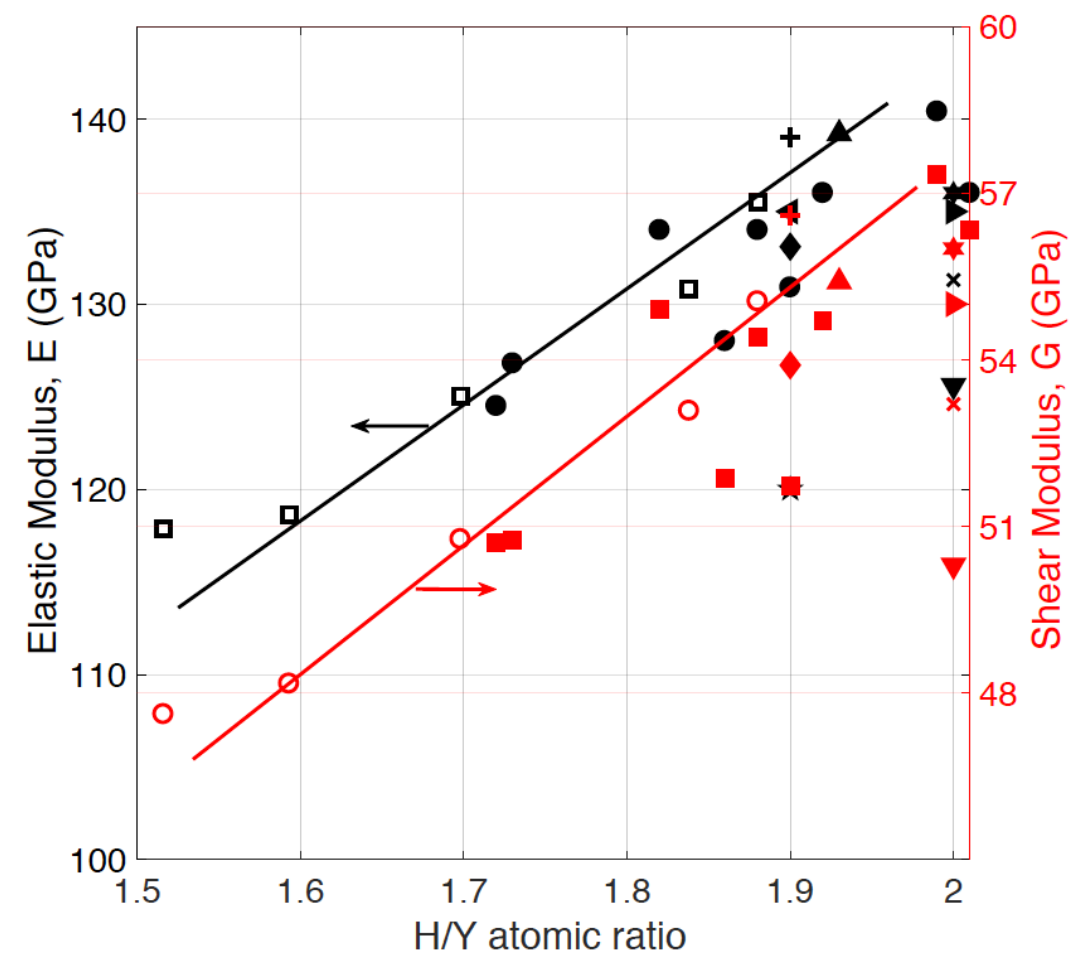

口 E, RUS, DH, This study

$\checkmark \mathrm{E}, \mathrm{DH}$ [Setoyama 2005] ${ }^{\star}$

$\Delta$ E, DH [Beattie 1972] ${ }^{*}$

- E, DH [lto 2008]*

E, DH [Schultz 2016] ${ }^{\%}$

+ E, RUS, SM [Shivprasad 2020]

4 E, NI, SM [Shivprasad 2020]

$\star$ E, NI, DH [Shivprasad 2020]

$\boldsymbol{\nabla}$ E, DFT [Shivprasad 2020]

× E, DFT [Yang 2013]

* E, DFT [Shucltz 2016]

$O \mathrm{G}, \mathrm{RUS}, \mathrm{DH}$, This study

$\Delta \mathrm{G}, \mathrm{DH}$ [Beattie 1972]*

$\checkmark \mathrm{G}, \mathrm{DH}$ [Setoyama 2005] ${ }^{\star}$

- G, DH [lto 2008]

G, DH [Schultz 2016] ${ }^{\%}$

+ G, RUS, SM [Shivprasad 2020]

$\nabla$ G, DFT [Shivprasad 2020]

$\times$ G, DFT [Yang 2013]

* G, DFT [Schultz 2016]

*Calculated using the longitudinal and shear sound velocity determined from ultrasonic pulse-echo testing;

$\%$ experimental method was not identified

DH: $\quad$ direct hydride

SM: $\quad$ sintered monolith

NI: nanoindentation

DFT: density functional theory simulation

Figure 7. Elastic and shear moduli of yttrium hydride as a function of $\mathrm{H} / \mathrm{Y}$ atomic ratio at room temperature together with literature data. Solid lines are fitting curves for the data points obtained in the present study. 


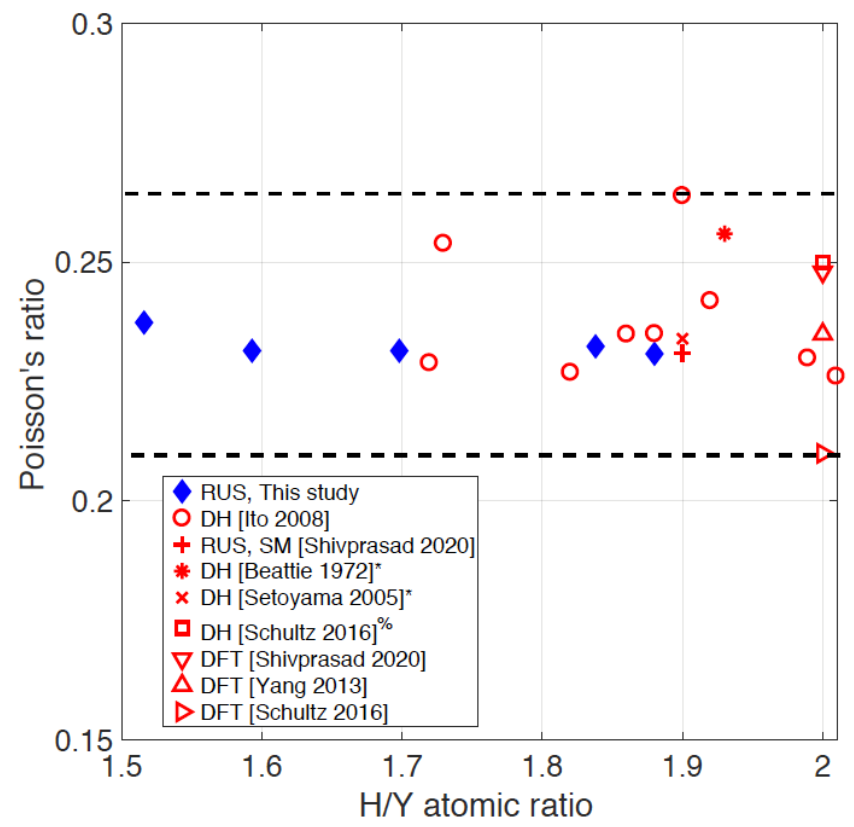

*Calculated using the longitudinal and shear sound velocity determined from ultrasonic pulse-echo testing; $\%$ experimental method was not identified

DH: $\quad$ direct hydride

SM: $\quad$ sintered monoliths $\mathrm{YH}_{\mathrm{x}}$

DFT: density functional theory simulation

\section{Figure 8. Poisson's ratio of $\mathrm{YH}_{\mathrm{x}}$ as a function of $\mathrm{H} / \mathrm{Y}$ atomic ratio at room temperature, together with literature data.}

\subsubsection{Fracture strength}

Under equibiaxial flexural testing, the specimen is loaded using a concentric ring-on-ring module until fracture occurs. The maximum load obtained in each test - practically, the fracture load - is converted to the equibiaxial strength at the surface of the disk specimen $\left(\sigma_{f}\right)$. The formula for the equibiaxial fracture strength, $\sigma_{f}$, of a circular plate specimen in units of MPa is given by Eq. (11) [13]:

$$
\sigma_{f}=\frac{3 F}{2 \pi h^{2}}\left[(1-v)\left(\frac{D_{S}^{2}-D_{L}^{2}}{2 D^{2}}\right)+(1+v) \ln \left(\frac{D_{S}}{D_{L}}\right)\right],
$$

where

$F=$ the breaking (fracture) load $[\mathrm{N}]$,

$h=$ the thickness of thin circular specimen $[\mathrm{mm}]$,

$D=$ the diameter of circular test specimen $[6 \mathrm{~mm}]$,

$D_{S}=$ the support ring diameter $[5 \mathrm{~mm}]$,

$D_{L}=$ the load ring diameter $[2 \mathrm{~mm}]$, and

$v=$ Poisson's ratio.

The Weibull probability of failure is calculated using $P_{f}=(i-0.3) /(N+0.4)$, where $i$ is the rank of failure strength in a set of $N$ data. Figure 9 shows the failure probability as a function of the corresponding equibiaxial flexural strength for $\mathrm{YH}_{\mathrm{x}}$ with an $\mathrm{H} / \mathrm{Y}$ atomic ratio from 1.00 to 1.87 . 


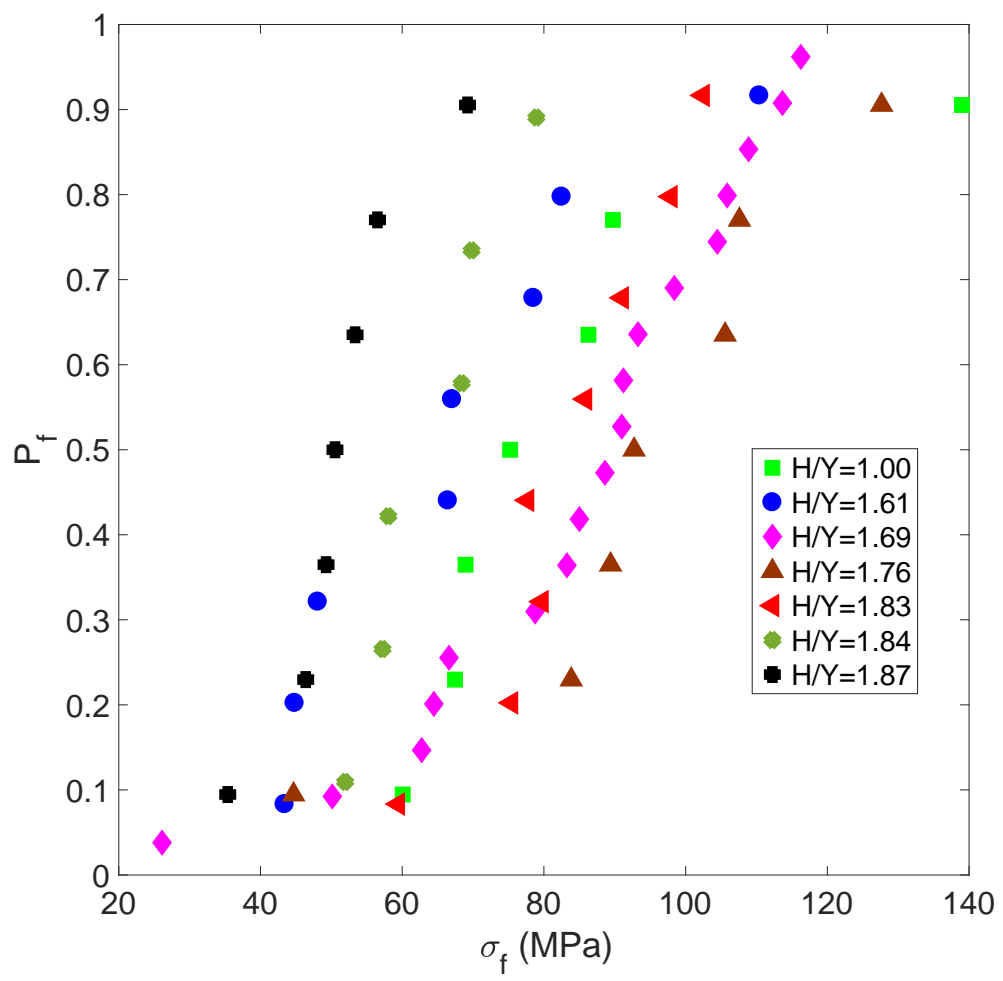

Figure 9. Plots of failure probability $\left(\mathbf{P}_{\mathrm{f}}\right)$ as a function of equibiaxial flexural strength for $\mathrm{YH}_{\mathbf{x}}$ with various hydrogen concentrations.

The two-parameter Weibull statistical treatment is often used to evaluate the statistical strength of brittle materials. The cumulative distribution function or probability of failure for the Weibull distribution is expressed by

$$
P_{f}\left(\sigma_{f}\right)=1-\exp \left[\frac{-1}{V_{c}} \int_{V}\left(\frac{\sigma_{f}}{\sigma_{0}}\right)^{m} d V\right]
$$

where $m$ is the Weibull modulus, and $\sigma_{0}$ is the characteristic strength that equals $\sigma_{f}$ when $P_{f}=0.632 . V_{c}$ is the characteristic test volume, and $V$ is the volume of the object to be analyzed using these Weibull parameters. $V_{c}$ is the volume of the material under the load ring that is subject to the maximum stress during the equibiaxial flexural test, which is $1.57 \mathrm{~mm}^{3}$. The formulation in Eq. (9) takes into account that failure in brittle materials occurs as a result of flaws. Since the probability of the presence of flaws is proportional to the volume of the material, this formulation allows the test data derived from miniature disks to be used to determine the failure probability for other geometries. For geometries distinct from that of the disks, the integration over the volume $V$ and normalization with $V_{c}$ produces the appropriate estimate for failure probability. If the fracture is believed to result from surface flaws, then area normalization may be applied in a similar manner. The characteristic test area here was $3.14 \mathrm{~mm}^{2}$.

The two parameters in the function, $m$ and $\sigma_{0}$, are also called the shape and scale parameters, respectively; they can be obtained by fitting the Weibull plot (Figure 9). The results are summarized in Table 2. Hydrogen concentration is not clearly dependent on these two parameters. The Weibull moduli measured range was from 3.0 to $\sim 7.0$, which is a typical range for brittle materials. The relatively small values of the scale parameter and the mean failure strength highlight the brittle nature of the studied $\mathrm{YH}_{\mathrm{x}}$ material. 


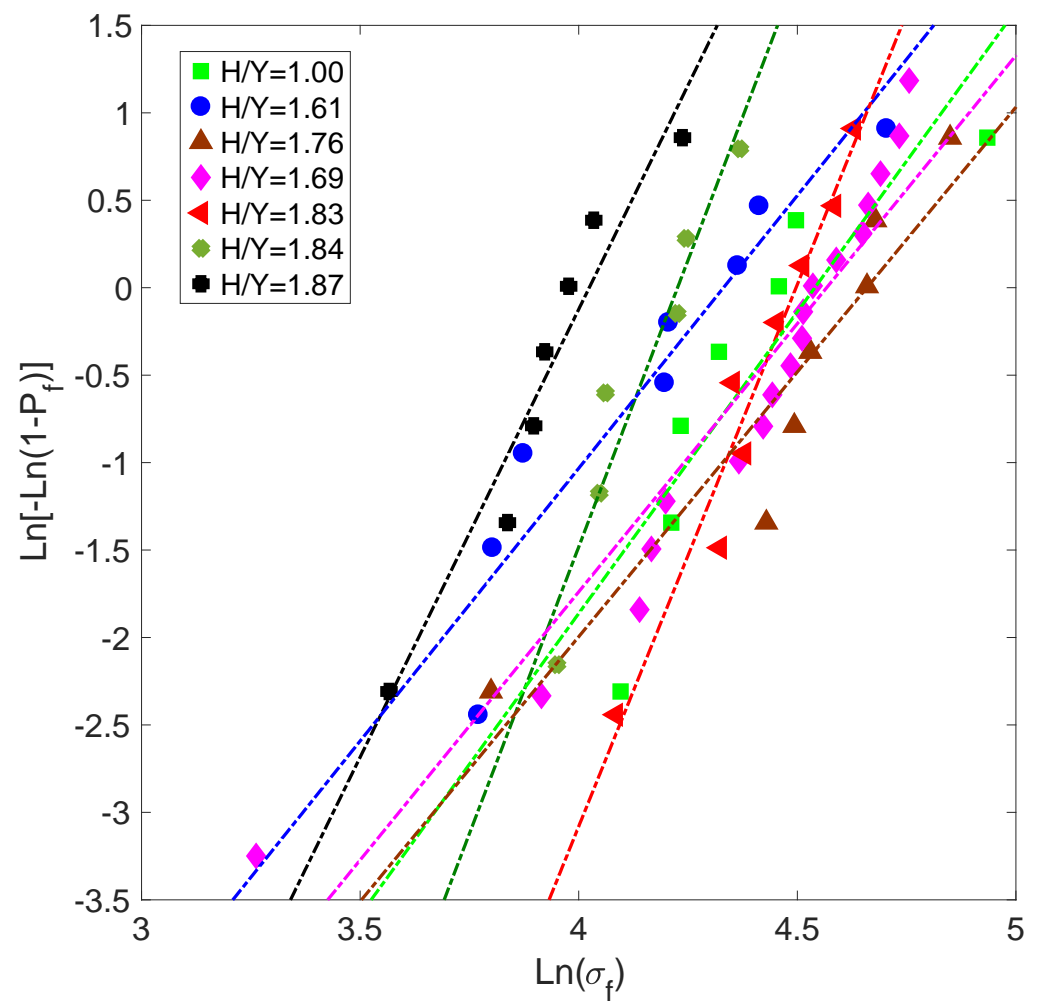

Figure 10. Weibull plots of the failure strength data of $\mathrm{YH}_{\mathbf{x}}(\mathrm{x}=1.00 \sim 1.87)$ determined from equibiaxial flexural strength testing.

Table 2. Summary of Weibull statistics analysis for the equibiaxial flexural strength testing with a characteristic test volume of $1.57 \mathrm{~mm}^{3}$

\begin{tabular}{|c|c|c|c|c|}
\hline $\begin{array}{c}\text { YHx } \\
(\mathbf{H} / \mathbf{Y})\end{array}$ & Dimension & $\begin{array}{c}\text { Weibull modulus, } \\
\mathbf{m}\end{array}$ & $\begin{array}{c}\text { Scale parameter } \\
(\mathbf{M P a})\end{array}$ & $\begin{array}{c}\text { Mean failure strength } \\
(\mathbf{M P a})\end{array}$ \\
\hline 1.00 & $\varnothing 5.8 \mathrm{~mm} \times 0.626 \mathrm{~mm}$ & 3.45 & 93.69 & 83.82 \\
\hline 1.61 & $\varnothing 5.8 \mathrm{~mm} \times 0.601 \mathrm{~mm}$ & 3.12 & 76.02 & 67.64 \\
\hline 1.69 & $\varnothing 5.8 \mathrm{~mm} \times 0.498 \mathrm{~mm}$ & 3.07 & 96.25 & 84.90 \\
\hline 1.76 & $\varnothing 5.8 \mathrm{~mm} \times 0.613 \mathrm{~mm}$ & 3.03 & 105.53 & 93.07 \\
\hline 1.83 & $\varnothing 5.8 \mathrm{~mm} \times 0.509 \mathrm{~mm}$ & 6.20 & 89.75 & 83.68 \\
\hline 1.84 & $\varnothing 5.8 \mathrm{~mm} \times 0.645 \mathrm{~mm}$ & 6.56 & 68.44 & 64.05 \\
\hline 1.87 & $\varnothing 5.8 \mathrm{~mm} \times 0.623 \mathrm{~mm}$ & 5.12 & 55.92 & 51.51 \\
\hline
\end{tabular}

\subsubsection{Microstructure}

Figure 11 shows the SEM/electron backscatter diffraction (EBSD) results of two types of samples: (1) disc hydride samples $\left(\mathrm{YH}_{1.70}\right.$ and $\left.\mathrm{YH}_{1.88}\right)$ sectioned from $\mathrm{YH}_{\mathrm{x}}$ rods (Figure 1) and $\mathrm{YH}_{\mathrm{x}}$ discs $\left(\mathrm{YH}_{1.69}\right.$ and $\mathrm{YH}_{1.83}$ ) directly fabricated from metallic yttrium discs (6 $\mathrm{mm}$ in diameter, $0.5 \mathrm{~mm}$ in thickness). The results indicate that twin structures are found in $\mathrm{YH}_{1.70}$ and $\mathrm{YH}_{1.88}$, implying that large internal stresses were generated during the hydriding process. The relatively fast hydrogen introduction rate $(50 \mathrm{sccm})$ results in a large hydrogen concentration gradient across the working piece. The differential volume expansion associated with the $\mathrm{H}$ distribution induces a buildup of the internal stress [14], contributing to the formation of the observed twin structures. Note that the stress is not sufficient to lead to cracking, and 
the material is sufficiently compliant at the elevated processing temperatures to deform and accommodate the differential volumetric expansion. In contrast, the application of a lower hydrogen loading rate (25 $\mathrm{sccm}$ ) yields a relatively uniform hydrogen distribution. Therefore, the internal stress is much less significant. $\mathrm{YH}_{1.69}$ and $\mathrm{YH}_{1.83}$ exhibit random grain structures, as seen in Figure 11(c) and (d). It was found that the average grain size of $\mathrm{YH}_{1.83}$ was smaller than that of $\mathrm{YH}_{1.69}$. More analysis is needed to confirm whether this trend will stand for hydride samples with different hydrogen concentrations. The results indicate that the grain structures of the as-fabricated $\mathrm{YH}_{\mathrm{x}}$ were strongly dependent on the processing method.
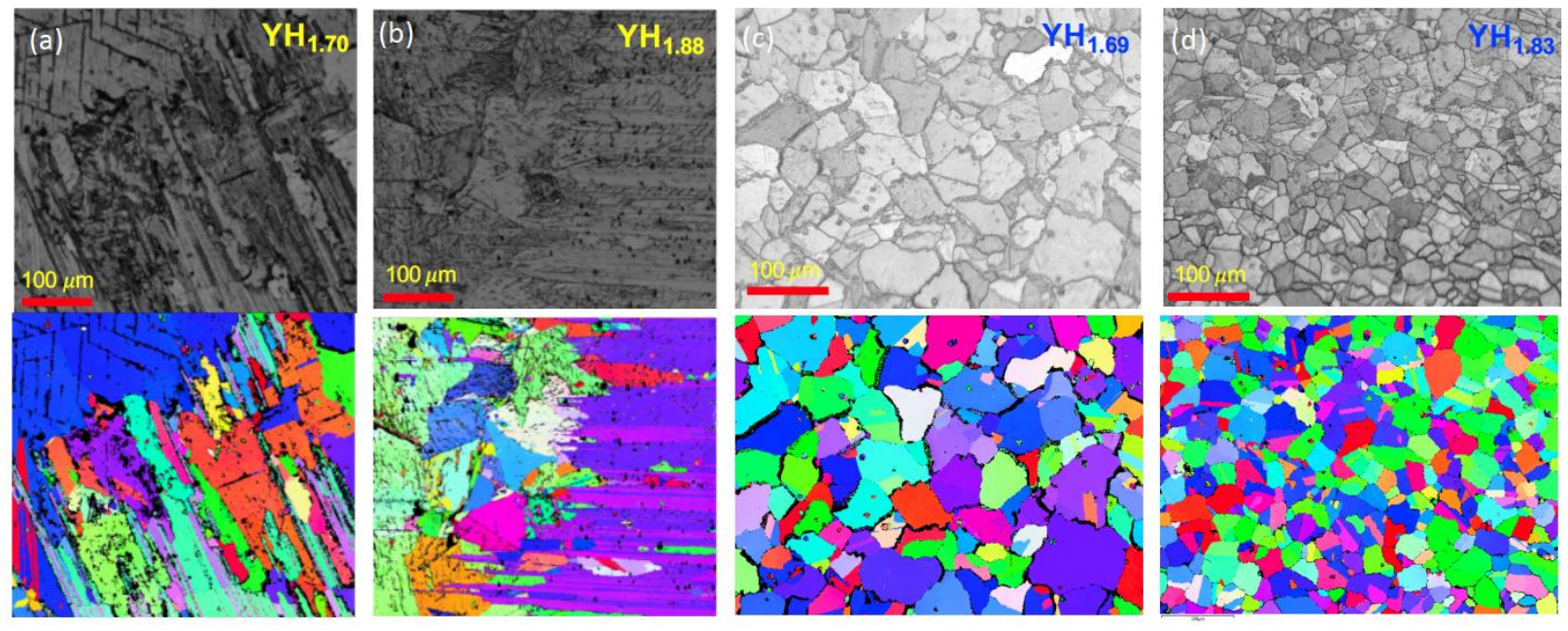

Figure 11. EBSD studies of (a) $\mathrm{YH}_{1.70}$, (b) $\mathrm{YH}_{1.88}$, (c) $\mathrm{YH}_{1.69}$, and (d) $\mathrm{YH}_{1.83}$. Band contrast images and inverse pole figures ( $\mathrm{Z}$ direction) are shown.

TEM examination was carried out to investigate the microstructural features at the nanoscale level. Figure 12 shows the high-angle annular dark-field (HAADF) images, as well as the elemental analysis.

Curtaining features found in the HAADF images are artifacts generated in the FIB sample preparation. The only obvious microstructural features are precipitates/particles that are 15 60 nm in diameter. For the two investigated samples, no obvious differences were found in the sizes and number densities of these particles. EDS analysis identified the presence of fluorine and calcium in these particles, which was expected because the industrial metal production route involves heating yttrium fluoride in the presence of calcium metal. The fluorine and calcium were present in the form of $\mathrm{CaF}_{2}$. 

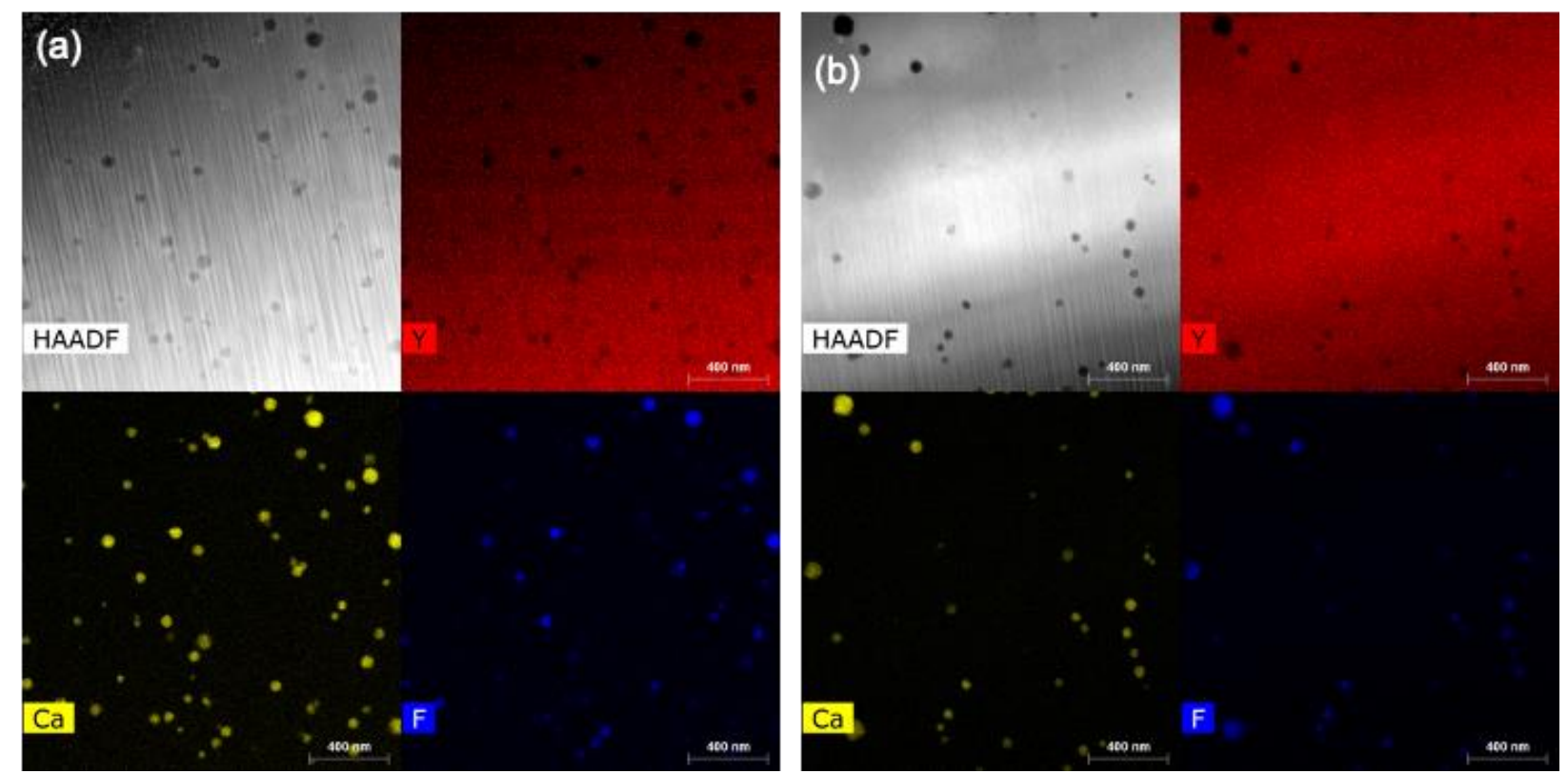

Figure 12. HAADF and x-ray maps of (a) YH1.69 and (b) YH1.83.

\subsubsection{Thermal Stability of Yttrium Hydride}

A thermodynamic driving force exists to establish a new equilibrium with the service environment of $\mathrm{YH}_{\mathrm{x}}$ at elevated temperatures. Therefore, hydrogen desorption from the hydride is expected, and a dynamic equilibrium is established once the environmental hydrogen partial pressure is equal to the equilibrium hydrogen pressure of $\mathrm{YH}_{\mathrm{x}}$ (the $\mathrm{H} / \mathrm{Y}$ atomic ratio decreases as a result of the release of hydrogen) at the operating temperatures. When $\mathrm{YH}_{\mathrm{x}}$ is located in an open space, hydrogen desorption from $\mathrm{YH}_{\mathrm{x}}$ will continue, and eventually all hydrogen will be lost, leaving pure yttrium behind. Therefore, a hydrogen barrier or control of hydrogen activity in the environment is required to enable the long-term operation of nuclear reactors that employ an $\mathrm{YH}_{\mathrm{x}}$ moderator. The hydrogen desorption rate at elevated temperatures is an indicator of the thermal stability of $\mathrm{YH}_{\mathrm{x}}$, providing a scientific base for the development of a hydrogen barrier. In the present study, thermal desorption spectroscopy (TDS) measurements under vacuum were carried out to evaluate the thermal stability of $\mathrm{YH}_{\mathrm{x}}$ by measuring the hydrogen desorption flux as a function of temperature. Figure 13 charts the thermal hydrogen desorption flux from $\mathrm{YH}_{\mathrm{x}}$ discs $(\sim 6 \mathrm{~mm}$ in diameter, $\sim 0.5 \mathrm{~mm}$ in thickness) with $\mathrm{H} / \mathrm{Y}$ atomic ratios of $1.76,1.84$, and 1.87 . The background hydrogen signal is also shown in the same plot. The temperature range of TDS is from room temperature to $1,173 \mathrm{~K}$ at a ramping rate of $0.5 \mathrm{~K} / \mathrm{s}$. However, the measurements of $\mathrm{YH}_{1.76}, \mathrm{YH}_{1.84}$, and $\mathrm{YH}_{1.87}$ stopped at $1,126 \mathrm{~K}, 1,068 \mathrm{~K}$, and $1,053 \mathrm{~K}$, respectively, because a significant pressure increase in the measurement chamber posed a risk of damage to the quadrupole mass spectrometer. Similar features were found in the measured hydrogen thermal desorption spectra. 


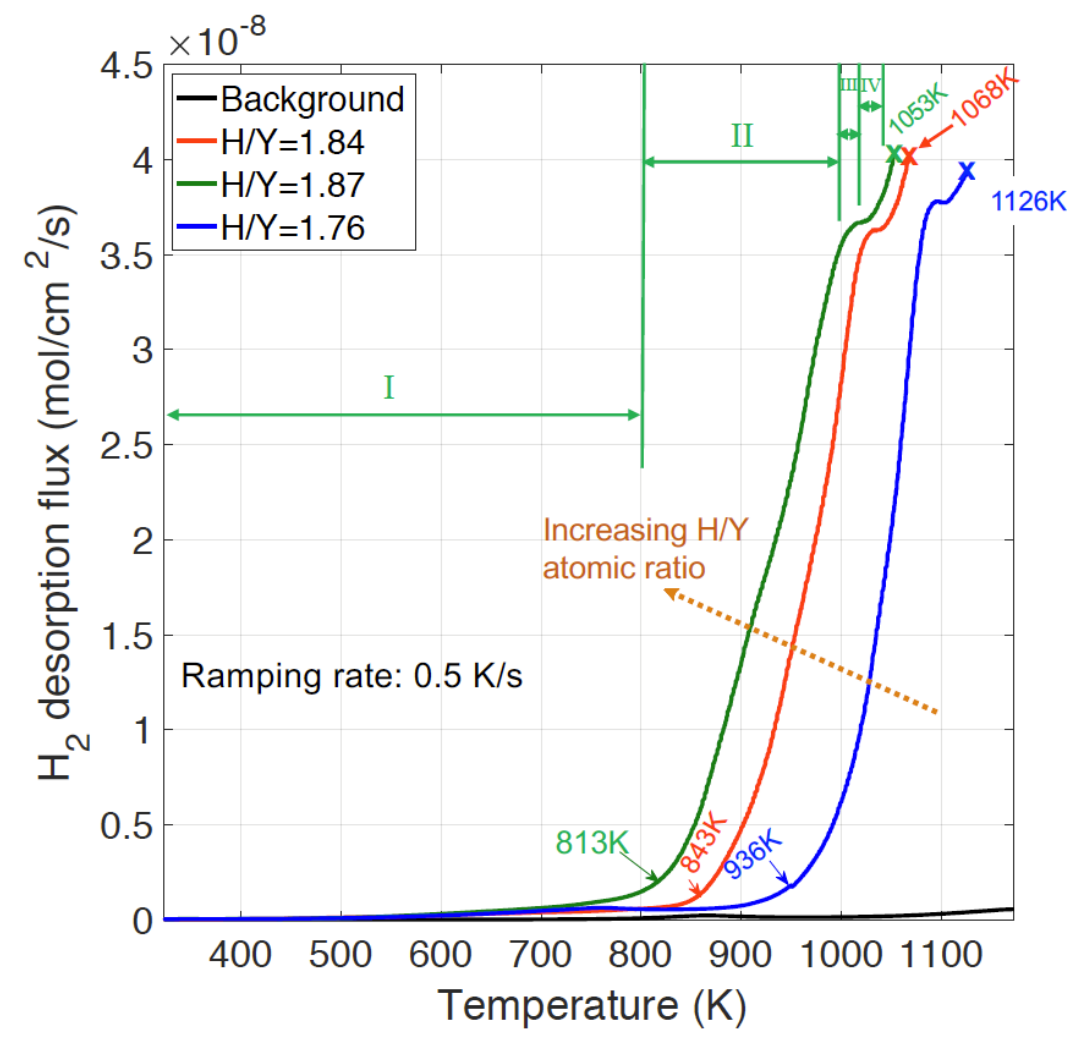

Figure 13. Hydrogen desorption flux from $\mathrm{YH}_{\mathrm{x}}(\mathrm{x}=1.76,1.84$, and 1.87) as a function of temperature measured by thermal desorption spectroscopy. The background signal is also shown. The temperature ramping rate is $0.5 \mathrm{~K} / \mathrm{s}$.

Four stages were identified in the dehydriding process, as shown in the hydrogen thermal desorption spectrum. Stage I refers to the temperature regime in which no significant hydrogen desorption was observed; Stage II covers the first linear increase region of the hydrogen desorption flux; Stage III is a short plateau with no significant variation in the measured hydrogen flux; and Stage IV is the other significant hydrogen release region until the end of the TDS measurements. The temperature range for each stage is listed in Table 3. It is apparent that the onset temperature of significant hydrogen desorption from $\mathrm{YH}_{\mathrm{x}}$ (Stage II) decreases with increasing $\mathrm{H} / \mathrm{Y}$ atomic ratio. It was concluded that the hydrogen desorption flux from $\mathrm{YH}_{\mathrm{x}}$ was a function of temperature and hydrogen concentration. This is different from the observations for $\delta$-phase $\mathrm{ZrHx}$, which showed no discernible hydrogen concentration dependence and a zero-order desorption kinetics [32,33]. More effort is needed to investigate the hydrogen desorption and absorption kinetics of $\mathrm{YH}_{\mathrm{x}}$, as well as the hydrogen mobility in $\mathrm{YH}_{\mathrm{x}}$.

Table 3. Temperature ranges of the four hydrogen desorption stages for tested samples

\begin{tabular}{|c|c|c|c|c|}
\hline Sample & Stage I & Stage II & Stage III & Stage IV \\
\hline $\mathrm{YH}_{1.76}$ & $300-936 \mathrm{~K}$ & $936-1,094 \mathrm{~K}$ & $1,094-1,106 \mathrm{~K}$ & $1,106-1,126 \mathrm{~K}$ \\
\hline $\mathrm{YH}_{1.84}$ & $300-843 \mathrm{~K}$ & $843-1,028 \mathrm{~K}$ & $1,028-1,042 \mathrm{~K}$ & $1,042-1,068 \mathrm{~K}$ \\
\hline $\mathrm{YH}_{1.87}$ & $300-813 \mathrm{~K}$ & $813-1,013 \mathrm{~K}$ & $1,013-1,028 \mathrm{~K}$ & $1,028-1,053 \mathrm{~K}$ \\
\hline
\end{tabular}

Although two phases - $\alpha$-phase yttrium and $\delta$-phase $\mathrm{YH}_{\mathrm{x}}$-were simultaneously present in the studied $\mathrm{YH}_{1.76}, \mathrm{YH}_{1.84}$, and $\mathrm{YH}_{1.87}$ at room temperature, the onset temperatures for significant hydrogen release from these three samples were all higher than the $\alpha-\delta$ phase transformation temperatures. Therefore, 
Stage II occurred in the pure $\delta$ phase $\mathrm{YH}_{\mathrm{x}}$. As shown by Hu et al. [33], the dehydriding process is diffusion limited. The continuous loss of hydrogen from the sample surface results in the buildup of the hydrogen concentration gradient. The near-surface regime reaches a point at which $\alpha$ yttrium precipitates out. Then the dehydriding process enters the two-phase moving boundary stage. The subsequent hydrogen loss eventually converts the material to a pure $\alpha$-yttrium. Therefore, Stage I involves two different regimes of hydrogen desorption from $\mathrm{YH}_{\mathrm{x}}$ : one with mixed phases, and one from single $\delta$-phase $\mathrm{YH}_{\mathrm{x}}$. Considering the extremely low hydrogen desorption flux, Stage I has little impact on the overall hydrogen concentration. Stage II corresponds to the hydrogen desorption from $\delta$-phase $\mathrm{YH}_{\mathrm{x}}$, implying a strong interdependence between temperature and hydrogen concentration. The nucleation process is short, but it is not an instantaneous process because of the complicated surface conditions, which probably are correlated to the Stage III. In response to the aforementioned dehydriding process, the incomplete Stage IV refers to the two-phase moving boundary stage.

\subsection{DISCUSSION}

It is apparent that all studied properties of $\mathrm{YH}_{\mathrm{x}}$ exhibited a clear dependence of hydrogen concentration. $\mathrm{YH}_{\mathrm{x}}$ is a class of metallic hydride - also known as interstitial hydride - which is formed through direct interaction of hydrogen and yttrium. In this type of hydride, the stoichiometric $\mathrm{YH}_{2}$ conforms to the fluorite structure $(\mathrm{Fm} \overline{3} \mathrm{~m})$, where metal yttrium atoms are arranged in an FCC lattice. Hydrogen prefers to occupy the lower energy tetrahedral locations between the yttrium atoms, thus forming a simple cubic lattice. The presence of hydrogen has significant effects on the band structure of the yttrium, and it introduces hydrogen-induced states below the $d$ band. The formation and characteristics of the metalhydrogen bonds in interstitial hydrides, which are formed from transition and rare earth elements, have been controversial for many years [34]. Two simple protonic and anionic models have been proposed to describe metal hydride electronic properties. In the protonic model, hydrogen is considered to donate its electrons to the $d$-band of the host element and exist as protons partially screened by the conduction electrons. In the anionic model, hydrogen is assumed to accept electrons from the host metal $d$-band. Fujimori and Schlapbach [35] report that a charge transfer from yttrium to hydrogen is evident in $\mathrm{YH}_{2}$ using $\mathrm{X}$-ray photoemission spectroscopy, thus indicating an anionic-type bonding of $\mathrm{Y}-\mathrm{H}$. The mechanical properties of $\mathrm{YH}_{\mathrm{x}}$ reported in Section 2.2.2.3 clearly indicate that $\mathrm{YH}_{\mathrm{x}}$ is inherently a brittle material, as manifested by the high values of hardness and modulus and the low values of the Weibull modulus and flexural strength. Like other ceramic materials, the nature of the embrittlement of $\mathrm{YH}_{\mathrm{x}}$ stems from the strong ionic Y-H bonding and the resultant lack of slip systems. Electronic structure study of LaHx [36] showed that with increasing hydrogen concentration, emission from the $d$ bands near Fermi level decreases, and the bonding band shifts to a higher binding energy. The same trend is expected for $\mathrm{YH}_{\mathrm{x}}$, as yttrium is also one of the rare earth elements, which partially rationalized the experimental observation that $\mathrm{YH}_{\mathrm{x}}$ with higher hydrogen concentration is more brittle. The other factor responsible for the enhanced embrittlement of $\mathrm{YH}_{\mathrm{x}}$ with higher $\mathrm{H} / \mathrm{Y}$ atomic ratio is that the tested $\mathrm{YH}_{\mathrm{x}}$ at room temperature is a mixture of $\alpha$-yttrium and $\delta$ - $\mathrm{YH}_{2}$, and the weight fraction of $\delta$ - $\mathrm{YH}_{2}$ increases with increasing hydrogen concentration, as indicated by the XRD analysis presented in Section 3.1.

For the thermophysical properties of $\mathrm{YH}_{\mathrm{x}}$ reported in Section 2.2.2, specific heat capacity is found to be increasing with increasing hydrogen concentration. The specific heat capacity, $C_{p}$, is the sum of four contributions: vibration of yttrium atoms for the acoustic mode, thermally driven dilation, the electronic term, and the vibration of hydrogen atoms for the optical mode. It is well established that the vibration of the metal element and hydrogen in the binary hydride contributes the most to the specific heat capacity [37] [13]. Ito [27] reports that the contribution from the hydrogen optical mode dominates when temperature is greater than $200 \mathrm{~K}$. Because the optical vibrational term of hydrogen is proportional to the hydrogen concentration, the specific heat capacity increases with increasing hydrogen concentration. Ito [27] reports that thermal diffusivity is independent of the hydrogen content for $\mathrm{YH}_{\mathrm{x}}$ with $1.70<\mathrm{x}<1.90$. However, Trofimov et al. [38] observe the hydrogen dependence of the measured thermal diffusivity in 
the same hydrogen content regime, although the difference is small. The same trend was found for $\mathrm{YH}_{\mathrm{x}}$ with $1.50<\mathrm{x}<1.60$. Ito [27] demonstrates that both electronic and phonon transport processes contribute to the thermal conductivity in yttrium hydride, with both of these two contributions having a larger magnitude than what exists in yttrium metal [10]. The increase of electron contribution for the hydride against that for the yttrium metal is attributed to the decrease of electrical resistivity [27]. The fact that $\mathrm{YH}_{\mathrm{x}}$ with higher hydrogen concentration has more $\delta$ phase hydride explains the observed hydrogen dependence of thermal diffusivity. However, the most important consideration may be that because phonon scattering is a key contributor to thermal resistivity in $\mathrm{YH}_{\mathrm{x}}$, higher $\mathrm{H} / \mathrm{Y}$ ratios closer to $\mathrm{YH}_{2}$ present fewer scattering sites (vacancies on the hydrogen sublattice) and therefore less scattering centers. In essence, $\mathrm{YH}_{\mathrm{x}}$ with larger $x$ should have higher thermal diffusivity. For the thermal conductivity, which is a product of density, specific heat capacity, and thermal diffusivity, it also exhibits an increasing trend for $\mathrm{YH}_{\mathrm{x}}$ with higher hydrogen content, as the variation in density with increasing hydrogen content is negligible, while both specific heat capacity and thermal diffusivity increase with increasing hydrogen content.

Section 2.2.2 shows that hydrogen dependence on the thermal expansion in the temperature regime before transition is limited. Beyond the transition temperature, $\mathrm{YH}_{\mathrm{x}}$ with a higher hydrogen concentration has a smaller CTE. Based on the phase diagram of Y-H binary system [39], a phase transformation from $\alpha-\mathrm{Y}$ to $\delta$ phase hydride is expected, and this process is accompanied by a 4\% 5\% volume expansion when temperature is beyond the transition value. Therefore, $\mathrm{YH}_{\mathrm{x}}$ with lower hydrogen concentrations will have a more significant volume expansion due to more $\alpha$-Y in the first place. The kinetic process of this phase transformation is under investigation.

\section{NEUTRON IRRADIATION RESPONSE OF YTTRIUM HYDRIDE}

The other property of $\mathrm{YH}_{\mathrm{x}}$ important for high-temperature moderator application is the neutron irradiation response. However, data for this property are scarce. The only available research on this topic was published in the 1960s, and it showed good in-pile thermal stability [40]. Detailed data on the impact of neutron irradiation on the thermomechanical properties of $\mathrm{YH}_{\mathrm{x}}$ are not available to date. Therefore, a campaign to irradiate $\mathrm{YH}_{\mathrm{x}}$ in HFIR was initiated in FY19 under the TCR program. The current results of these efforts are detailed below. Properties being investigated include swelling, heat capacity, thermal diffusivity, thermal expansion, hardness, and fracture toughness. Furthermore, as many of the properties are known to be strongly dependent on hydrogen content, $\mathrm{YH}_{\mathrm{x}}$ samples with various hydrogen concentrations are being tested.

\subsection{IRRADIATION CAPSULE DESIGN}

In this experiment, the rabbit capsule is loaded with a sealed molybdenum holder that contains the diskshaped $\mathrm{YH}_{\mathrm{x}}$ specimens and their associated components, as shown in Figure 14. On each side of the holder's interior, eight $6 \mathrm{~mm}$ diameter specimens are lined with four silicon carbide (SiC) pieces $24 \mathrm{~mm}$ in length. These are separated by two additional pieces of $\mathrm{SiC}$ retainers $48 \mathrm{~mm}$ in length and two thin $\mathrm{SiC}$ retainer springs bent to press the specimen assemblies to the holder wall. Four SiC slabs that are $24 \mathrm{~mm}$ in length that are serving as thermometry are placed between the sample layer and the SiC retainers. The holder features welded end caps on each side to mitigate the potential of hydrogen release from the sample holder to the external $\mathrm{Al}$ housing, thus minimizing the hydrogen diffusing into HFIR coolant. Molybdenum was specifically chosen due to its performance at high temperatures, frequency of use in similar experiments, and its anticipated resistance to hydrogen chemical interactions and leakage [41]. Figure 15 shows the samples and parts layout for the irradiation capsule of YHXT01 before assembly. 


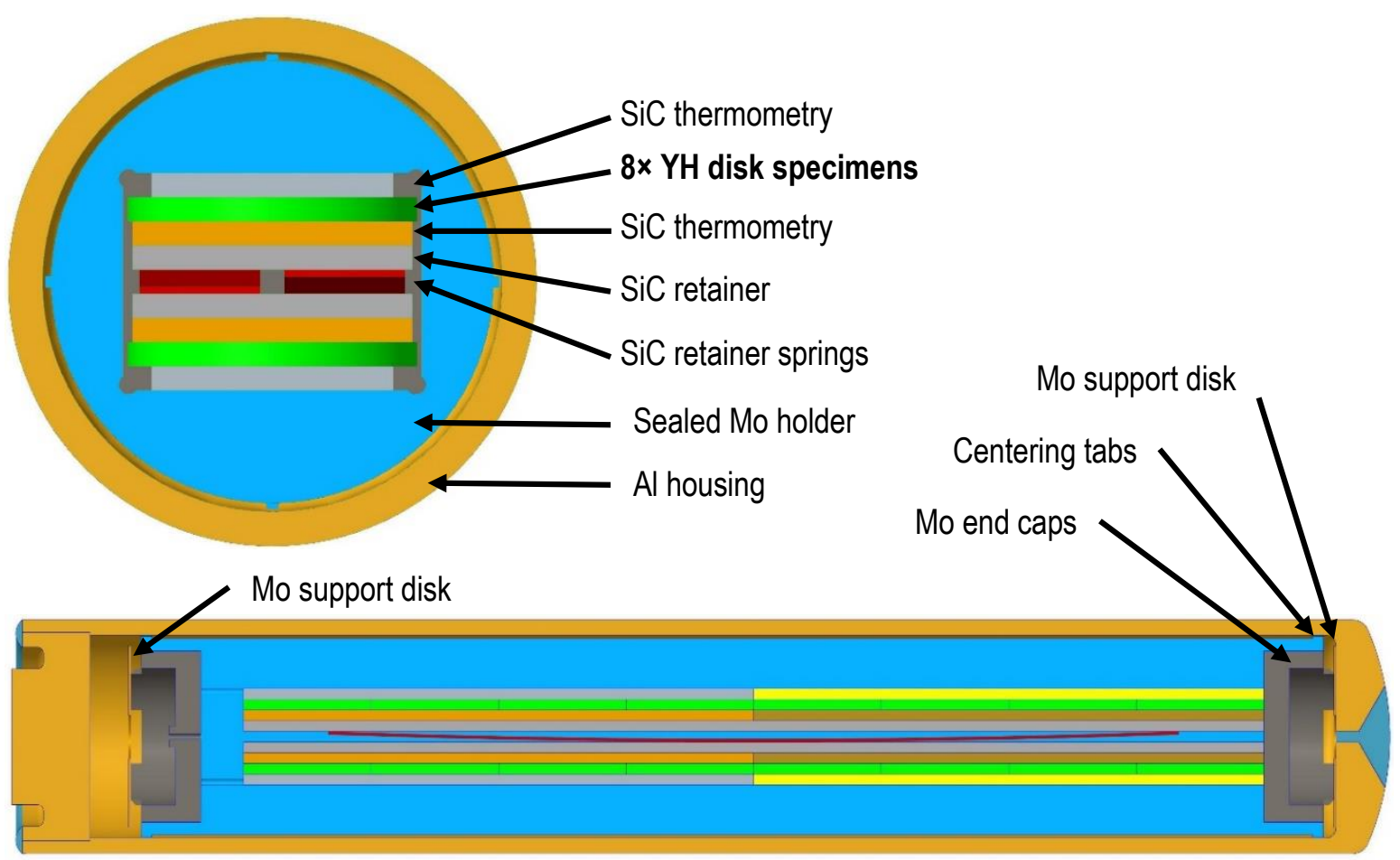

Figure 14. Design of $\mathrm{YH}_{\mathrm{x}}$ irradiation capsule [41].

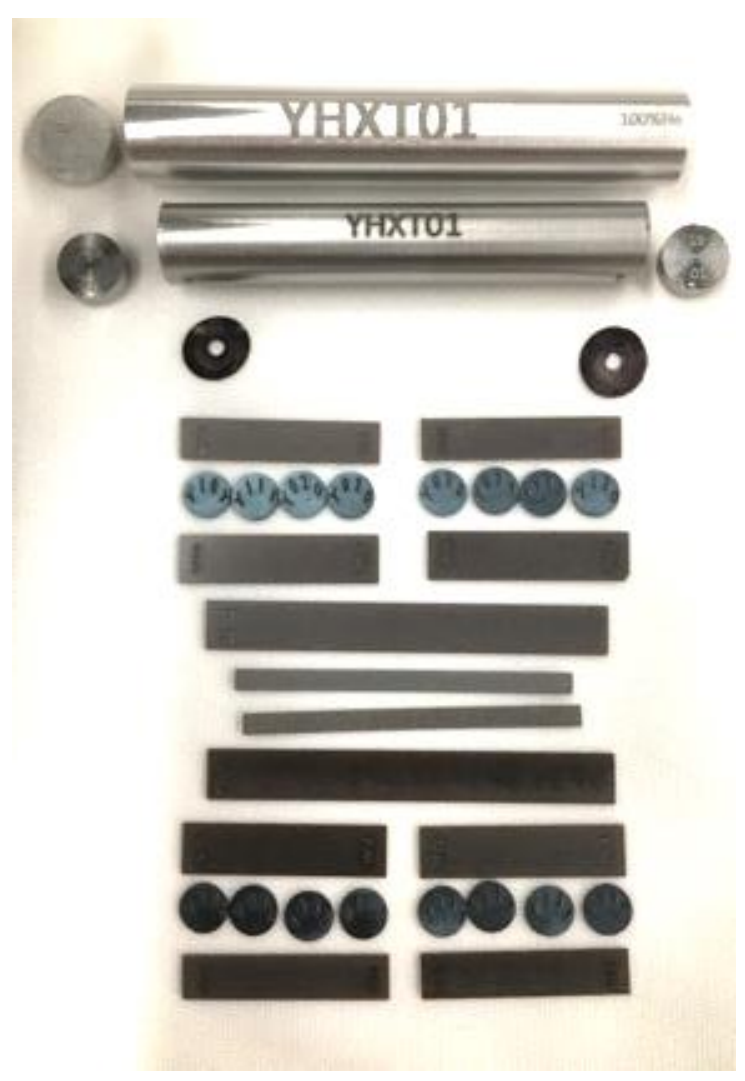

Figure 15. Samples and parts of YHT01. 
This experiment consisted of twelve rabbits in total, representing two hydrogen concentrations $\left(\mathrm{YH}_{1.72}\right.$ and $\left.\mathrm{YH}_{1.83}\right)$, two design temperatures $\left(600\right.$ and $\left.900^{\circ} \mathrm{C}\right)$, and three specimen doses $(0.1,1$, and $2 \mathrm{dpa})$, as shown in Table 4. This would require placing eight rabbits in the hydraulic tube for partial cycles and four in the permanent facilities for a single cycle. These twelve rabbit capsules containing $192 \mathrm{YH}_{\mathrm{x}}$ disks $(6$ $\mathrm{mm}$ in diameter, $0.5 \mathrm{~mm}$ in thickness) were irradiated in the HFIR flux trap during cycles 487 (May 2020) and 488 (June 2020).

Table 4. Irradiation test matrix

\begin{tabular}{|c|c|c|c|}
\hline $\begin{array}{l}\text { Capsule } \\
\text { ID }\end{array}$ & $\begin{array}{l}\text { Irradiation } \\
\text { temperature }\end{array}$ & Dose (dpa) & Material \\
\hline YHXT01 & \multirow{3}{*}{$600^{\circ} \mathrm{C}$} & 0.1 & \multirow{6}{*}{$\mathrm{YH}_{1.7}$} \\
\hline \begin{tabular}{|l|} 
YHXT02 \\
\end{tabular} & & 1 & \\
\hline YHXT13 & & 2 & \\
\hline YHXT04 & \multirow{3}{*}{$900^{\circ} \mathrm{C}$} & 0.1 & \\
\hline YHXT05 & & 1 & \\
\hline YHXT14 & & 2 & \\
\hline YHXT07 & \multirow{3}{*}{$600^{\circ} \mathrm{C}$} & 0.1 & \multirow{6}{*}{$\mathrm{YH}_{1.83}$} \\
\hline YHXT08 & & 1 & \\
\hline \begin{tabular}{|l|} 
YHXT09 \\
\end{tabular} & & 2 & \\
\hline YHXT10 & \multirow{3}{*}{$900^{\circ} \mathrm{C}$} & 0.1 & \\
\hline YHXT11 & & 1 & \\
\hline YHXT12 & & 2 & \\
\hline
\end{tabular}

\subsection{POST-IRRADIATION EXAMINATION (PIE)}

Following neutron irradiation in HFIR, all irradiation capsules were shipped to the hot cell. All irradiation capsules have been disassembled until June 2021. SiC thermometry plates of the twelve capsules were successfully extracted and shipped to LAMDA for measurement. In addition, all $32 \mathrm{YH}_{\mathrm{x}}$ samples of YHXT07 and YHXT10 were shipped to LAMDA for thermomechanical property measurement. The remaining samples are still stored in the hot cell at this writing and will be transported to LAMDA soon. This report presents the thermal property data of the samples available at LAMDA.

\subsubsection{Irradiation Temperature Determination}

The SiC thermometries (TMs) were analyzed via dilatometry measurements to confirm the irradiation temperature. The irradiation temperatures from the calculation - which was based on the assembled dimensions of capsule internals and core locations of rabbit capsules - are shown in Figure 16, along with the experimental thermometry measurements. The actual temperatures, which were within $2-9 \%$ of the design target temperatures, were determined from experimental analysis of TM coupons after irradiation. Although these actual irradiation temperatures do not precisely match the target irradiation temperatures in planning (i.e., 600 and $900^{\circ} \mathrm{C}$ ), they still comply well with the original intention of the experiment to test $\mathrm{YH}_{\mathrm{x}}$ materials at representative middle and high irradiation temperatures that can cover the possible operation temperature range of the TCR core. 


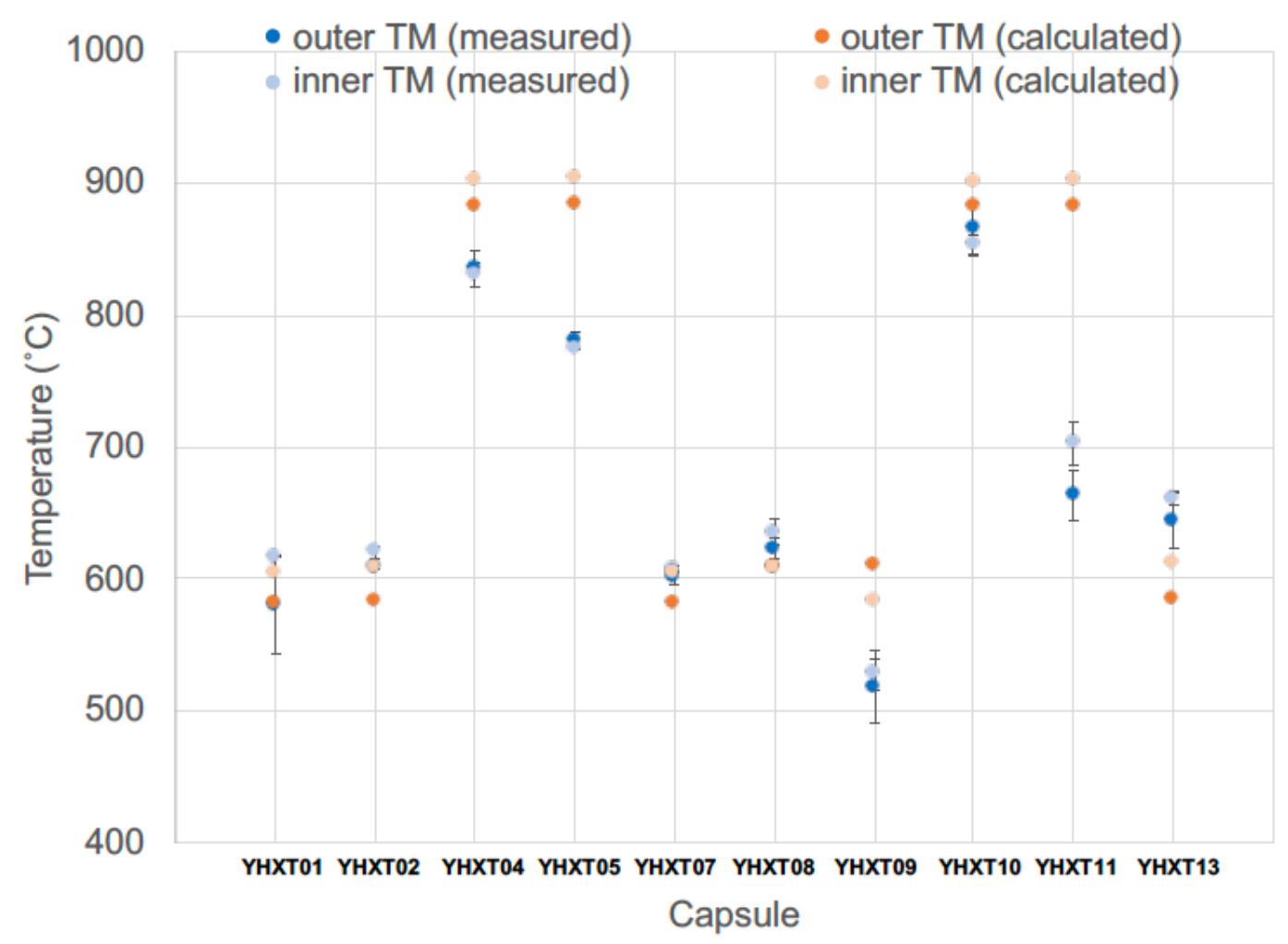

Figure 16. Irradiation temperature determined from SiC thermometry compared with calculated values for different irradiation capsules.

\subsubsection{Thermal Diffusivity}

Thermal diffusivity of irradiated $\mathrm{YH}_{\mathrm{x}}$ was determined following the same procedure as shown in Section 2.1.2. The results of the samples from YHXT07 and YHXT10 are shown in Figure 17. It is apparent that the thermal diffusivity of irradiated $\mathrm{YH}_{\mathrm{x}}$ showed a decline trend with increasing temperature, which is similar to that observed for reference $\mathrm{YH}_{\mathrm{x}}$ samples. After the low-dose irradiation, there is insignificant change with respect to the thermal diffusivity, although a slightly higher thermal diffusivity of irradiated samples was observed when the temperature was higher than $300^{\circ} \mathrm{C}$. When comparing the samples irradiated at 600 and $900^{\circ} \mathrm{C}$, no obvious irradiation temperature dependence was found on the measured thermal diffusivity. 


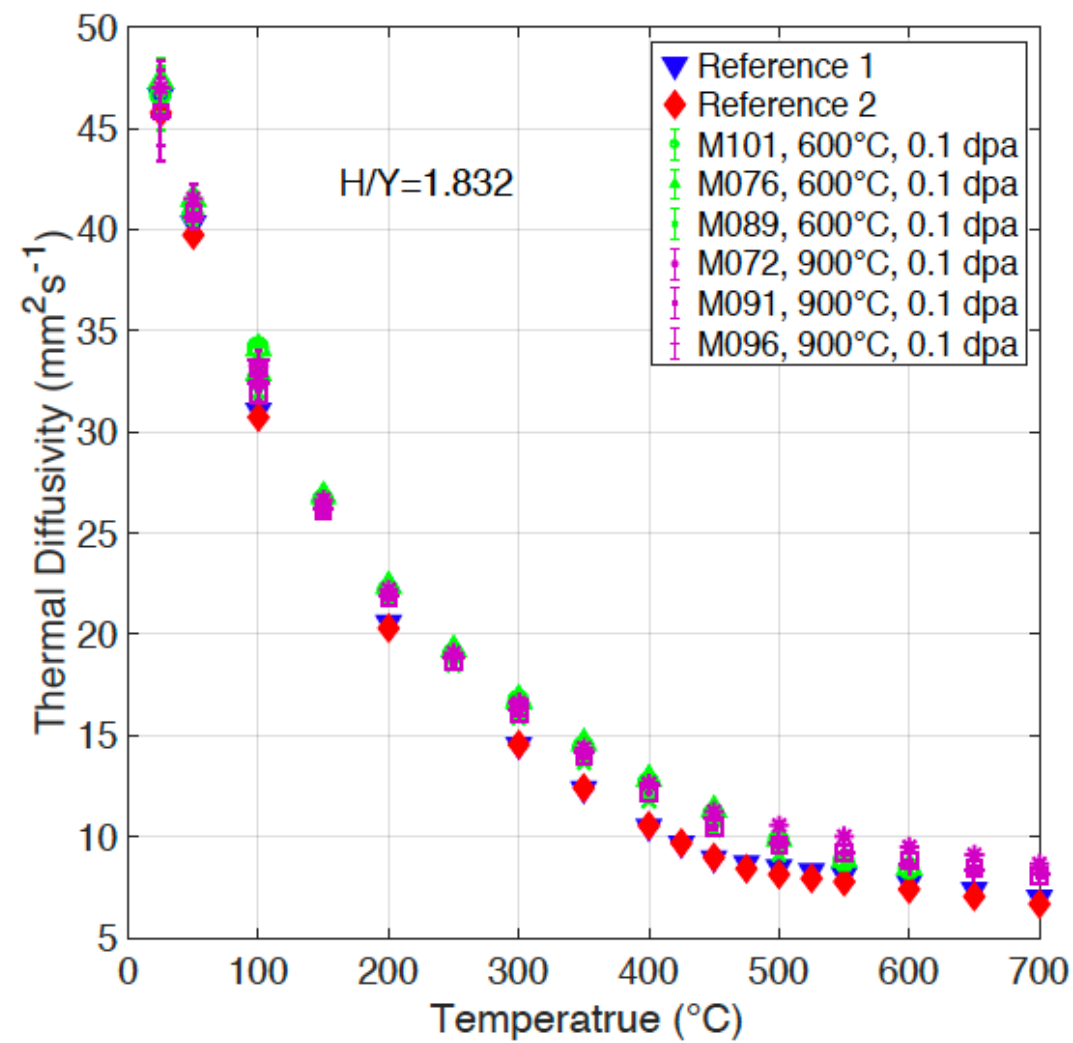

Figure 17. Thermal diffusivity of $\mathrm{YH}_{\mathrm{x}}$ before and after neutron irradiation $\left(600\right.$ and $\left.900^{\circ} \mathrm{C}, 0.1 \mathrm{dpa}\right)$.

\subsubsection{Post-Irradiation Examination Plan}

Microstructural characterization is being performed on the extracted samples from the two irradiation samples that were shipped to LAMDA. Characterization includes SEM/EDS and TEM. Powder XRD will also be performed to identify the phases present within the irradiated materials. Hardness and fracture strength testing are also planned and will be performed soon. Coordination with hot cell staff is under way to facilitate the shipment of the remaining irradiation capsules to LAMDA for detailed PIE.

\section{CHALLENGES AND RESEARCH NEEDS}

The deployment of $\mathrm{YH}_{\mathrm{x}}$ as a moderator in advanced nuclear reactors requires development of a complete thermomechanical property database for this material. $\mathrm{YH}_{\mathrm{x}}$ is perceived as a promising high-temperature $(>873 \mathrm{~K})$ moderator material. However, the high-temperature properties of $\mathrm{YH}_{\mathrm{x}}$ are scarcely reported in the literature. Measuring the thermomechanical properties of $\mathrm{YH}_{\mathrm{x}}$ at elevated temperatures is challenging; the hydrogen loss during measurements, which leads to a change in the hydrogen content of the tested specimen, is the primary concern. The extent of hydrogen release is a function of testing temperature and duration. Based on the thermal stability study, hydrogen desorption is negligible when specimens are tested at temperatures lower than the transition temperature point from Stage I to II. A hydrogen management strategy needs to be developed for testing at higher temperatures. This strategy may include encapsulation of tested specimens or establishment of a dynamics equilibrium environment via flowing hydrogen gas with a pressure that corresponds to the equilibrium hydrogen pressure of the tested specimen at the testing temperature. 
Similarly, long-term operation of reactors using $\mathrm{YH}_{\mathrm{x}}$ as a moderator requires careful management of hydrogen retention, as $\mathrm{YH}_{\mathrm{x}}$ dissociates to metal yttrium and hydrogen at elevated temperatures. Flowing hydrogen at a specific pressure is sufficient to maintain the $\mathrm{H} / \mathrm{Y}$ atomic ratio in the initial $\mathrm{YH}_{\mathrm{x}}$ material during lab testing. However, that strategy will require careful consideration in real reactor applications, as thermal gradients across the core and the $\mathrm{YH}_{\mathrm{x}}$ moderator are expected because of the non-uniform reactor power distribution. Under the same environmental hydrogen pressure, the low-temperature zones of the hydride will have high hydrogen content due to additional absorption of hydrogen from the flowing gas. This process is well understood based on the pressure-composition-temperature map of the binary Y-H system. It is unclear how the redistribution of the hydrogen within the hydride will impact the neutronic performance of the $\mathrm{YH}_{\mathrm{x}}$ moderator; this issue must be assessed based on the specific design of the reactor core. Moreover, the exposure of a metal hydride to flowing gas has the potential to introduce oxygen into the reactor core. As the affinity of yttrium for oxygen is insatiable and the oxygen solubility in yttrium is high (10 at. \% at 1,273 K), the $\mathrm{YH}_{\mathrm{x}}$ moderator will act as an oxygen absorber during the operation, resulting in additional safety and performance concerns. A more practical method to mitigate hydrogen loss is to develop cladding protection as a barrier. The down-selection of cladding materials will consider hydrogen permeability, neutronic property, chemical compatibility with $\mathrm{YH}_{\mathrm{x}}$, radiation stability, and fabricability. In the TCR, SS316L was selected as the near-term viable cladding for the $\mathrm{YH}_{\mathrm{x}}$; its hydrogen permeability was deemed sufficiently low for the operating regime of the TCR, as it would have little impact on the hydrogen content of the moderator material. However, better cladding materials with lower neutron absorption cross sections and lower permeability to hydrogen are necessary for long-term use in high-temperature nuclear reactors. More work is needed to develop a hydrogen barrier for $\mathrm{YH}_{\mathrm{x}}$ moderators.

In addition, under the influence of a thermal gradient, the hydrogen in hydrides migrates from hightemperature zones into low-temperature zones (i.e., the Soret effect). However, the thermal migration of hydrogen within $\mathrm{YH}_{\mathrm{x}}$ has not yet been studied yet. Following the thermal migration study of zirconium hydride described in Vetrano [2], the heat of transport for hydrogen migration in $\mathrm{YH}_{\mathrm{x}}$ can be obtained by redistributing hydrogen within the hydride sample $\left(\mathrm{YH}_{\mathrm{x}}\right.$ rod) under a linear temperature gradient. More fundamental research on the hydrogen mobility as a function of hydrogen content in $\mathrm{YH}_{\mathrm{x}}$ would benefit the accurate prediction of hydrogen redistribution in the service environment.

\section{CONCLUSION}

This milestone report provides a summary compilation of the properties of unirradiated $\mathrm{YH}_{\mathrm{x}}$, including density, crystal structure, specific heat capacity, thermal diffusivity, thermal conductivity, hardness, elastic/shear moduli, Poisson's ratio, fracture strength, microstructure, and thermal stability —all of which were measured using various characterization techniques. The correlation between the studied properties and the hydrogen concentration is revealed and reported here, and the preliminary PIE data of the irradiated $\mathrm{YH}_{\mathrm{x}}$ is provided. Some of these results are also presented in a recent article by Hu and Terrani [42].

- $\quad \mathrm{XRD}$ analysis indicated that both $\alpha$-phase yttrium and $\delta$-phase $\mathrm{YH}_{\mathrm{x}}$ were present in the studied hydride materials at room temperature. The fraction of the $\delta$-phase $\mathrm{YH}_{\mathrm{x}}$ increased with increasing $\mathrm{H} / \mathrm{Y}$ atomic ratio, whereas the dependence of the hydrogen concentration on the lattice parameter of $\mathrm{YH}_{\mathrm{x}}(1.50<\mathrm{x}<1.92)$ was negligible.

- Measurements of specific heat capacity, thermal diffusivity, and calculated thermal conductivity all showed a similar $\mathrm{H} / \mathrm{Y}$ ratio dependence at lower temperatures $(<573 \mathrm{~K})$, with the values being slightly higher for the larger $\mathrm{H} / \mathrm{Y}$ ratios, whereas thermal expansion had a negligible composition dependence in the low temperature regime. The higher temperature data revealed a change in the 
material's response in relation to all investigated properties. The observed reversible transitions had a second-order and endothermic nature, and the transition temperature was inversely proportional to the hydrogen content.

- Measured hardness and elastic properties showed a linear correlation with the hydrogen concentration at room temperature.

- The fracture strength determined from the equibiaxial flexural strength test method highlighted the brittle nature of $\mathrm{YH}_{\mathrm{x}}$, and no clear hydrogen dependence was found in the Weibull moduli and scale parameters.

- Microstructural characterization of $\mathrm{YH}_{\mathrm{x}}$ indicates that the grain structure is highly dependent on the fabrication process. Calcium and fluorine impurities in the starting yttrium metal resulted in distributed nanoparticles in the fabricated hydride.

- To facilitate the deployment of a high-temperature $\mathrm{YH}_{\mathrm{x}}$ moderator, other important, much-needed properties that have not been investigated were also discussed.

- Following 0.1 dpa irradiation in HFIR, insignificant change was found in the measured thermal diffusivity.

\section{REFERENCES}

1. Christy, R. F. and A. M. Weinberg, Light Water Moderated Neutronic Reactor. US Patent, 1946. App. No. US640100A.

2. Vetrano, J. B., "Hydrides as Neutron Moderator and Reflector Materials." Nuclear Engineering and Design, 1971. 14(3): pp. 390-412.

3. Mueller, W. M., J. P. Blackledge, and G. G. Libowitz, Metal Hydrides. Academic Press New York and London, 1968.

4. Davies, N. and R. Forrester, Effects of Irradiation on Hydrided Zirconium-Uranium Alloy NAA 1204 Experiment. 1970, Atomics International Div.: Canoga Park, CA.

5. Simnad, M., "The U-ZrHx Alloy: Its Properties and Use in TRIGA Fuel." Nuclear Engineering and Design, 1981. 64(3): pp. 403-422.

6. Haslett, R., Space Nuclear Thermal Propulsion Program. 1995, Grumman Aerospace Corp.: Bethpage, NY.

7. Begun, G. M., J. F. Land, and J. T. Bell, "High Temperature Equilibrium Measurements of the Yttrium-Hydrogen Isotope (H2, D2, T2) Systems." The Journal of Chemical Physics, 1980. 72(5): pp. 2959-2966.

8. "Advanced Small Modular Reactors," US Department of Energy. https://www.energy.gov/ne/nuclear-reactor-technologies/small-modular-nuclear-reactors, accessed June 2021.

9. Oak Ridge National Laboratory, "Transformational Challenge Reactor." https://tcr.ornl.gov, 2019, accessed June 2021.

10. Ito, M. et al., "Thermal Properties of Yttrium Hydride." Journal of Nuclear Materials, 2005. 344(13): pp. 295-297. 
11. Setoyama, D. et al., "Mechanical Properties of Yttrium Hydride." Journal of Alloys and Compounds, 2005. 394(1-2): pp. 207-210.

12. Shivprasad, A. P. et al., "Elastic Moduli of High-Density, Sintered Monoliths of Yttrium Dihydride." Journal of Alloys and Compounds, 2020: p. 153955.

13. Shivprasad, A. P. et al., "Thermophysical Properties of High-Density, Sintered Monoliths of Yttrium Dihydride in the Range 373-773 K." Journal of Alloys and Compounds, 2021. 850.

14. Hu, X. et al., "Fabrication of Yttrium Hydride for High-Temperature Moderator Application." Journal of Nuclear Materials, 2020. 539: p. 152335.

15. Larson, A. C. and R. B. Von Dreele, General Structure Analysis System, Los Alamos National Laboratory Report LAUR 86-748, 2004.

16. ASTM E1269-11, Standard Test Method for Determining Specific Heat Capacity by Differential Scanning Calorimetry. 2018, ASTM International: West Conshohocken, PA.

17. ASTM E1461-07, Standard Test Method for Thermal Diffusivity by the Flash Method. 2007, ASTM International: West Conshohocken, PA.

18. Cowan, R. D., "Pulse Method of Measuring Thermal Diffusivity at High Temperatures." Journal of Applied Physics, 1963. 34(4): pp. 926-927.

19. Clark III, L. M. and R. E. Taylor, "Radiation Loss in the Flash Method for Thermal Diffusivity." Journal of Applied Physics, 1975. 46(2): pp. 714-719.

20. ASTM C1499-09(2013), Standard Test Method for Monotonic Equibiaxial Flexural Strength of Advanced Ceramics at Ambient Temperature. 2013.

21. Hu, X. et al., "Impact of Neutron Irradiation on Thermal Helium Desorption from Iron." Journal of Nuclear Materials, 2017. 489: pp. 109-117.

22. $\mathrm{Hu}, \mathrm{X}$. et al., "Microstructural Evolution of 3C-SiC Exposed to Simultaneous Neutron Irradiation and Helium Implantation." Journal of Nuclear Materials, 2018. 509: pp. 366-376.

23. Lundin, C. E. and J. P. Blackledge, "Pressure-Temperature-Composition Relationships of the Yttrium-Hydrogen System." Journal of The Electrochemical Society, 1962. 109: pp. 838-842.

24. Khatamian, D. and F. D. Manchester, "H-Y (Hydrogen-Yttrium)." Binary Alloy Phase Diagram, 1990. 2: pp. 2074-2075.

25. Trofimov, A. A. et al., "Thermophysical Properties and Reversible Phase Transitions in Yttrium Hydride." Journal of Nuclear Materials, 2021. 544: p. 152569.

26. Parker, D. S., USAEC Report APEX-588. General Electric Company, 1960.

27. Ito, M., Studies on Physical Properties of Metal Hydrides and Hydrogen Behavior in Zr Alloys. Osaka University, 2008. PhD Thesis.

28. Schwarz, R. B. and J. F. Vuorinen, "Resonant Ultrasound Spectroscopy: Applications, Current Status and Limitations." Journal of Alloys and Compounds, 2000. 310: pp. 243-250.

29. Beattie, A. G., Acoustic Velocity Measurements in the Metal Hydrides, ScH1.99, YH1.93, and ErH1.81. Journal of Applied Physics, 1972. 43(7): pp. 3219-3221.

30. Schultz, P. A. and C. S. Snow, "Mechanical Properties of Metal Dihydrides." Modelling and Simulation in Materials Science and Engineering, 2016. 24(3). 
31. Yang, J. W., T. Gao, and L. Y. Guo, "Ab Initio Study of the Structural, Mechanical, and Dynamical Properties of the Rare-Earth Dihydrides XH2 (X=Sc, Y, and La)." Physica B: Condensed Matter, 2013. 429: pp. 119-126.

32. Terrani, K. A. et al., "The Kinetics of Hydrogen Desorption from and Adsorption on Zirconium Hydride." Journal of Nuclear Materials, 2010. 397(1-3): pp. 61-68.

33. Hu, X., K. A. Terrani, and B.D. Wirth, "Hydrogen Desorption Kinetics from Zirconium Hydride and Zirconium Metal in Vacuum." Journal of Nuclear Materials, 2014. 448(1-3): pp. 87-95.

34. Jinwoo, H., Nuclear Magnetic Resonance Studies of Metal-Hydrogen Systems. PhD thesis, Iowa State University, 1988.

35. Fujimori, A. and L. Schlapbach, "Electronic Structure of Yttrium Hydride Studied by X-ray Photoemission Spectroscopy. Journal of Physics C: Solid State Physics," 1984. 17: pp. 341-351.

36. Peterman, D. J., J. H. Weaver, and D. T. Peterson, "Electronic Structure of Metal Hydrides. V.xDependent Properties of LaHx $(1.9<\sim x<\sim 2.9)$ and $\mathrm{NdHx}(2.01<\sim x<\sim 2.27)$. Physical Review B, 1981. 23(8): pp. 3903-3913.

37. Kurosaki, K. et al., "Isotope Effect and Hydrogen Content Dependence on the Heat Capacity and Thermal Conductivity of Zirconium Hydride and Deuteride." Journal of Nuclear Science and Technology, 2015. 53(4): pp. 508-512.

38. Trofimov, A. A. et al., "Thermophysical Properties and Reversible Phase Transitions in Yttrium Hydride." Journal of Nuclear Materials, 2020. 542.

39. Peng, J., et al., "Thermodynamic Modelling of $\mathrm{Y}-\mathrm{H}$ and $\mathrm{Y}-\mathrm{Zr}-\mathrm{H}$ System Aided by First-Principles and Its Application in Bulk Hydride Moderator Fabrication." Journal of Nuclear Materials, 2020. 531.

40. Marshall, J. C., R. Van Houten, and W. G. Baxter, Yttrium Hydride Moderator Evaluation-In-Pile Thermal Stability. NSA-18-004306, 1962.

41. Champlin, P. A. et al., Capsule and Specimen Geometries for HFIR Irradiation Testing Supporting the Transformational Challenge Reactor, Oak Ridge National Laboratory Report, ORNL/TM2019/1310, 2019.

42. $\mathrm{Hu}, \mathrm{X}$. and K. A. Terrani, "Thermomechanical properties and microstructures of yttrium hydride." Journal of Alloys and Compounds, 2021. 867. 
